\title{
Cam Lif Takviyeli Betonun Yangın Dayanımlarının Çeşitli Parametreler Açısından İrdelenmesi
}

\author{
Ali Murthada Ali ${ }^{1}$, Musa Hakan Arslan ${ }^{1, *}$, Mustafa Altın² ${ }^{\mathbb{C}}$ \\ ${ }^{1}$ Konya Teknik Üniversitesi, Mühendislik ve Doğa Bilimleri Fakültesi, 42070, Konya. \\ ${ }^{2}$ Konya Teknik Üniversitesi, Teknik Bilimler Meslek Yüksekokulu, 42130, Konya.
}

\section{Özet}

Cam lifi taze beton karıșımına eklenerek betonun mekanik özellikleri iyileştirilmektedir. Literatürde cam lif takviyeli betonun (CTB) mekanik özelliklerinin tespitine yönelik çok sayıda araştırma yapılmıştır. Beton içine cam lifi eklenerek özellikle betonun eğilme ve çekme dayanımında hatırı sayılır artışlar meydana gelmekte, bu şekilde üretilmiş olan betonlar daha ince kesitli oldukları için de uygulamada tercih edilmektedirler. Betonun içine eklenen cam lifinin betonun yangin performansina olumsuz bir etki yapıp yapmadiğına yönelik kapsamlı bir araştırma olmadı̆̆ için bu çalışmada dört farklı (30,60, 90 ve 120 dk) yangın sürelerine tabi tutulmuş cam lif takviyesiz beton ile CTB elemanlarının yangın sonrasındaki mekanik özelliklerindeki değișiklikler incelenmiştir. Deneysel çalışma kapsamında $\varnothing 15 / 30 \mathrm{~cm}$ silindir ve $4 \times 4 \times 16 \mathrm{~cm}$ prizmadan oluşan toplam 300 adet numune üretilmiştir. Numunelerde kullanılan 0,5,10,15 ve $20 \mathrm{~kg} / \mathrm{m}^{3}$ oranlarındaki cam elyaf takviyeli betonların değişik sürelerde yangın sonrasindaki basınç ve üç farkl çekme (yarma, tek noktadan eğilme ve iki noktadan eğilme) dayanımı üzerindeki etkisi farklı sürelerde yangına maruz bırakılan CTB elemanları üzerinden test edilmiştir. Yangın geçirmemiş numunelerde cam lifi basınç dayanımına bir katkıda bulunmazken çekme dayanımında önemli oranlarda katkısı olmuştur. 30 dakikalık yangın sonrasında CTB numunelerin tek ve çift noktadan eğilme deneylerinden elde edilen çekme dayanımlarında yangın öncesine göre bir artış görülmüş̧ür. Daha uzun süreli yangınlarda (60, 90 ve $120 \mathrm{dk}$ ) ise bu oranda bir artış meydana gelmemiştir.

\section{Anahtar Sözcükler}

Yangın, Beton, Cam Lif Takviyeli Beton, Mekanik Özellik

\section{Evaluation of Fire Resistance of Glass Fibre Concrete in Terms of Various Parameters}

\begin{abstract}
The mechanical properties of the concrete are improved by adding glass fiber to the fresh concrete mixture. Numerous studies have been carried out in the literature to determine the mechanical properties of glass fiber reinforced concrete (GRC). By adding glass fiber into the concrete, the bending and tensile strength of it increase considerable, and concretes produced in this way are preferred in practice to be thinner. Since there is no comprehensive investigation of the fire performance of the GRC used in practice, this study examined the changes in the mechanical properties of GRC elements subjected to four different (30,60, 90 and 120 min) fire periods. In the scope of the experimental study, 300 samples including $015 / 30 \mathrm{~cm}$ cylinder and $4 x 4 x 16 \mathrm{~cm}$ prism were produced. The effect of glass fiber admixture of $0,5,10,15$ and $20 \mathrm{~kg} / \mathrm{m}^{3}$ on the compressive and different tensile strength of the concrete was tested on GRC elements exposed to fire for different periods of time. A significant contribution of glass fiber to the tensile strength for unburned samples has been observed, however glass fiber does not contribute to the compressive strength. After 30 minutes of fire, tensile strengths of single and double point bending tests of GRC samples increased. In the case of longer fires, there has not been an increase in this rate.
\end{abstract}

$\underline{\text { Keywords }}$

Fire, Concrete, Glass Fiber Reinforced Concrete, Mechanical Property

\section{Giriş}

Beton oldukça geniş kullanım alanına sahip bir yapı malzemesidir. Betonun en iyi mekanik özelliği olan basınç dayanımı betonun diğer mekanik özelliklerinin de bir göstergesidir. Betonun gerilme-deformasyon ilişkisinden gevrek bir malzeme olduğu bilinmektedir. Bununla beraber çekme gerilmeleri altında basınç gerilmesine nazaran kapasitesinin oldukça yetersiz olduğu ise açıktır. Betonun özellikle çekme dayanımın artırılmasına yönelik pek çok çalışma yapılmıştır. Bunlardan en yaygın olanları taze betona ilave edilen liflerdir. Beton içerisine lifler katılmakla betona yeni özellikler kazandırmakta ve belli mekanik özellikleri arttırılmaktadır (Arslan ve Ulucan 1997). Betona ilave edilen farklı türdeki lifler ile elde edilen betonlara "Lif Takviyeli Beton"lar denilmektedir. 
Günümüzde betonda yaygın olarak kullanılan lifler; çelik, polimer (polipropilen, PVA), cam ve karbon esaslıdır. Betona liflerin eklenmesi; Betonun çekme ve eğilme mukavemetini, enerji tüketim kapasitesini ve çatlak büyüme özelliklerini iyileştirmek için en etkili yöntemlerden biridir (Kurt 2006). Bir lif çeşidi olan cam lif kullanılarak yapılan cam lif takviyeli beton (CTB); çimento, agrega ve süreksiz dağılmış liflerin suyla karıştırılmasıyla elde edilen kompozit bir malzeme olarak tanımlanabilir.

Beton bir bütün olarak düşünüldüğünde, içindeki sertleşmiş çimento hamuru ve agrega gibi bileşenlerin termal genleşmelerinin birbirinden farklı olduğu bilinmektedir. Bu nedenle, betondaki sıcaklık değişimleri, içerisindeki bileşenlerde birbirinden farklı hacim değişmelerine, çatlak oluşumuna ve betonun dayanımının azalmasına neden olmaktadır. Bu olay "betondaki bileşenlerin termal uyumsuzluğu” olarak bilinmektedir (Şimşek ve Sancak 2005). Sertleşmiş çimento hamuru oda sıcaklığından yaklaşık $150{ }^{\circ} \mathrm{C}$ ye 1 sitıldığında maksimum \%0,2 oranında genleşir (Cruz ve Gillen 1980). Sicaklık $150^{\circ} \mathrm{C}$ den $300^{\circ} \mathrm{C}$ ' ye arttırıldığı zaman sertleşmiş çimento hamuru büzülmeye başlar. Sicaklık $800{ }^{\circ} \mathrm{C}$ ' ye arttırıldığında ise çimento hamurundaki büzülme $\% 2,2$ ye kadar çıkabilir. Genellikle, $150{ }^{\circ} \mathrm{C}$ 'nin üzerindeki yüksek sıcaklıklarda agregalar genleşip dağılmaya başlarken, hidratasyon ürünlerinin dehidratasyonu sonucu çimento pastası büzüşür. Bu nedenle, yüksek sıcaklık şartları altında termal genleşmeler ve çatlamalar gelişir (Anwar Hossain 2006). Bu açıdan bakıldığı zaman betonun yüksek sıcaklık altındaki davranışı merak uyandırmaktadır.

Betonda yüksek sıcaklık etkisinde ile oluşacak hasarın önlenmesi için polipropilen ve çelik lifler kullanılmaktadır. Örneğin polipropilen lifler $170^{\circ} \mathrm{C}$ 'de eriyerek kanallar oluşturur, bu kanallar gazların dışarı çıkmasını sağlar ve boşluk basıncını azaltarak betonda oluşan hasarın derecesini azaltır (Kalifa vd. 2001; Cülfik ve Özturan 2002; Sakr ve Hakim 2005).

CTB ile literatürde çok fazla sayıda çalışma mevcuttur (Kurt 2006; Bölükbaş 2011; Kavas ve Sabah 2001; Lau ve Anson 2006; Peng vd. 2008; Şimşek ve Sancak 2005; Uysal 2004; Arioz 2007; Chen ve Liu 2004; Sertbaş 2015; Riad vd. 2015; Li vd. 2004; Tassew ve Lubell 2014; Keleştemur vd. 2014). Yapılmış bu çalışmalarda temel amaç CTB’nin farklı mekanik özelliklerinin belirlenmesidir. Bununla beraber cam lif kullanıldığı zaman yüksek sıcaklık ya da yangın etkisinde betonda olumsuz bir davranış oluşup oluşmadığı literatürde detaylı olarak incelenmemiş ve bu çalışmanın temel motivasyonunu oluşturmaktadır.

Yapı elemanlarının yangın ya da yüksek sıcaklıklara iyi bir direnç göstermeleri beklenmektedir. Özellikle yüksek sıcaklık altında yapı elemanlarında ani göçmelerin olmaması yapı elemanlarından beklenmektedir. Tasarım aşamasında deprem, rüzgar, ani mesnet çökmesi vs. gibi durumlar için yapılan analizler ya da simülasyonlar yangın için yapılmamaktadır. Bununla beraber özel amaçlı yapılar için (endüstriyel tesis, termik santraller, bacalar vb. gibi) yangın senaryolarına göre taşıyıcı sistemde ve kullanılan malzemeler için gerekli önlemler alınmaktadır. Yüksek sıcaklığa maruz kalan beton basınç mukavemetinin bir kısmını kaybeder. $300^{\circ} \mathrm{C}$ 'nin üzerinde sıcaklıklarda beton basınç dayanımında belirgin kayıpların olduğu literatürde belirtilmektedir. Basınç mukavemetindeki azalma miktarı, kullanılan malzemelerin özelliklerine ve ulaşılan en yüksek sıcaklık, 1sıtma hızı, ısıtma süresi, soğutma şekilleri gibi değişkenlere göre farklılık gösterir. Son yıllarda binalarda yaşanan yangınlar, bina içinde kullanılan yapısal olan/olmayan elemanların yangın dayanımları ile ilgili alınması gereken tedbirlerin önemini göstermektedir. Her türlü yapıda kaplama malzemesi olarak kullanılabilen CTB'ların yangın sırasındaki davranışı bu açıdan önemlidir. CTB özellikle prestij binaları başta olmak üzere birçok kamu ve devlet binasında kullanım alanı artan bir malzemedir. Bu malzemelerin yangın performansı ile ilgili yapılan bu çalışma, hem üretici hem uygulayıcılar hem de literatür açısından temel bir kaynak özelliği taşıyacağ düşünülmektedir.

$\mathrm{Bu}$ çalışmanın amacı çeşitli yangın sürelerine tabi tutulmuş (çeşitli sıcaklık seviyelerinde test edilmiş) CTB elemanlarının mekanik özelliklerini deneysel olarak ölçerek, yangın sonrasında cam lifinin betonun davranışında nasıl bir değişiklik oluşturduğunu incelemektir. Deneysel çalışma kapsamında $\varnothing 15 / 30 \mathrm{~cm}$ silindir ve $4 \times 4 \times 16 \mathrm{~cm}$ prizmadan oluşan toplam 300 adet numune üretilmiştir. Numunelerde $0,5,10,15$ ve $20 \mathrm{~kg} / \mathrm{m}^{3}$ oranlarındaki cam elyaf kullanılmıştır. Üretilen numuneler dört farklı (30,60, 90 ve $120 \mathrm{dk})$ yangın etkisine tabi tutulmuştur. Numunelerin yangın sonrasındaki basınç ve üç farklı çekme (yarma, tek noktadan eğilme ve iki noktadan eğilme) dayanımı değerleri tespit edilmiş ve elde edilen sonuçlar karşılaştırılmıştır.

\section{Beton İçerinde Kullanılan Lif Çeşitleri}

Beton içerisinde yaygın olarak kullanılan lifler; çelik, polipropilen, karbon ve alkali dirençli cam liflerdir. Lifli betonlarda, bütün lif çeşitlerinde sağlanması gereken en önemli özellik liflerin beton içerisinde homojen olarak dağılması ve bu dağılımın beton karıştırıldıktan sonra da bozulmamasıdır. Üniform bir şekilde dağılan lifler, beton içerisinde oluşan çatlakları önlemekte ve çatlakların beton içerisinde ilerlemesini yavaşlatarak betonu daha dayanıklı hale getirdiği bilinmektedir. Her bir lif türünün kendine özgü mekanik ve boyut özelliği vardır. Bundan dolayı kullanılacak alana göre lif çeşidi seçilebilir. Amerikan Test ve Malzeme Kuruluşu'na göre (ASTM 2009), bir malzemenin lif olarak

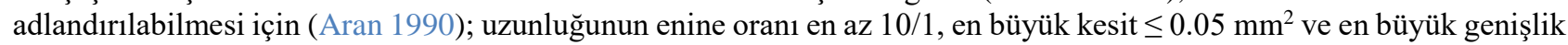
$\leq 0.25 \mathrm{~mm}$ olmalıdır. Liflerin ince üretimi ile büyük kütle yapılarına kıyasla daha az yapısal kusura sahiptirler. Bu nedenle, aynı maddenin elyaf biçimi üstün mekanik özelliklere sahiptir. Lifler genel olarak doğal ve yapay olmak üzere ikiye ayrilırlar (Bölükbaş 2011). 
Doğadan elde edilen ve çok az işlem gören bu elyaflar ekonomiktir ve kolaylıkla elde edilebilir oldukları için tercih edilirler. Lif takviyeli kompozitleri yapmak için kullanılan en eski doğal elyaf samandır. Yapay lifler doğal hammaddelerin çeşitli işlemler ile lif haline dönüştürülmesi ile üretilmektedir. Madensel, polimer ve cam lif olmak üzere üç farklı türü vardır. CTB'nin içeriğini oluşturan cam lifler camların elektrikli firında yaklaşık $1200-1500{ }^{\circ} \mathrm{C}$ 'de eritilmesi ve ergimiş camların platin alaşımlı bir potanın altındaki binlerce delikten geçerek ve bir soğutma bölgesinin içinden geçerek üretilir. Daha sonra, liflere kaplamalar uygulayarak ve onları demet halinde sararak depolanırlar. Cam liflerin çekme mukavemeti çok yüksektir bu nedenle betonun zayıf olan çekme dayanımını artırırlar. Şekil 1'de cam lif örneği verilmiştir.

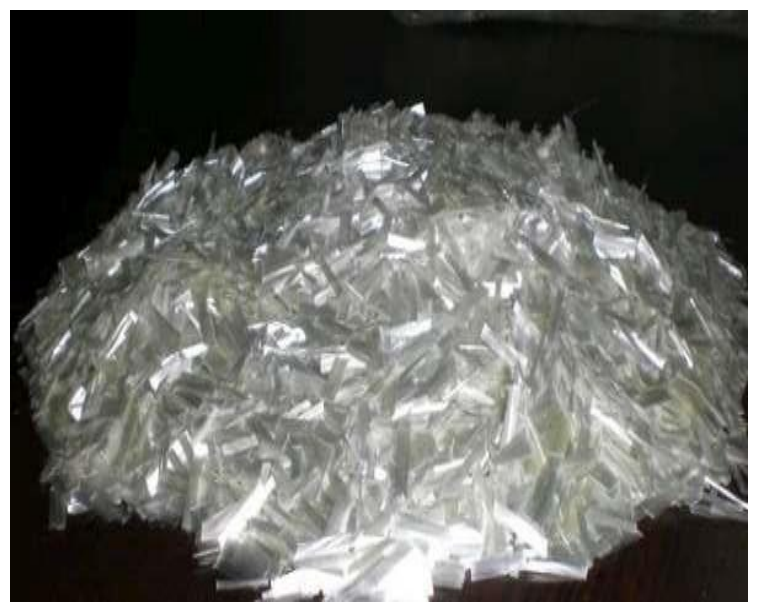

Şekil 1: Cam elyafı örneği

\section{Yangın Kavramı}

CTB numunelerinin yangın performanslarının test edilmesi için bu çalışmada doğal yolla çıkarılmış yangın deneyleri yapılmıştır. Yangın deneylerinden önce yangın kavramı ile ilgili bazı bilgilerin sunulması faydalı olacaktır. Bir yangının çıkması ve gelişmesi için yanıcı bir malzeme, oksijen ve 1sı kaynağının bir arada bulunması gerekir. Isı, sıcaklıkla ölçülebilen bir enerji olarak tanımlanmaktadır. Yanıcı maddeler incelendiğinde, en önemli özellikleri hangi sıcaklıkta tutuştuklarıdır. Tüm yanıcı maddeler bir tutuşma kaynağı (alev, kıvılcım, elektrik) ile karşılaştığında bir süre sonra tutuşacaktır. Bunun yanında bazı yanıcı maddeler belirli bir sıcaklığa ulaştıklarında da tutuşabilmektedirler.

Tutuşma sıcaklığı; yanıcı maddenin tutuşması için gereken havadaki minimum sıcaklıktır, 1sınmış olarak tutuşma kaynağı olmaksızın tutuşmaya başlaması ve devam ettirmesi olarak tanımlanmaktadır. Yanıcı madde, yangın durumunu çeşitli şekillerde etkiler. Yanıcı maddenin yangın çevresinde davranışını etkileyen ana parametreler, yanıcı maddenin durumu ve formudur (biçimi, kalınlığı, yüzeysel karakteri, dağılımı, yoğunluğu vb.). Yanma hızı ise, yanma bölgesinde oksijenin yenilenme olanaklarıyla orantılıdır (Uysal 2004).

Deneysel çalışmalarda, test edilen elemanlar genellikle ISO 834 (2014) standart yangın eğrisine göre tanımlanan yangına maruz bırakılırlar. Şekil 2'de gösterilen eğri, zaman ve sıcaklık değişimine göre ISO 834 standart yangın eğrisidir. Dünyanın birçok ülkesinde yapılan deney ve çalışmalarda yangın davranışlarının belirlenmesi için birebir ölçekli ya da farklı ölçeklerdeki numuneler üzerinde yangın deneyleri yapılmaktadır. Bu deneylerde kullanılan sıcaklık-zaman eğrileri standart yangın eğrileridir. Bu yangın modellerinde odanın gaz sıcaklığı uniform olarak alınmaktadır.

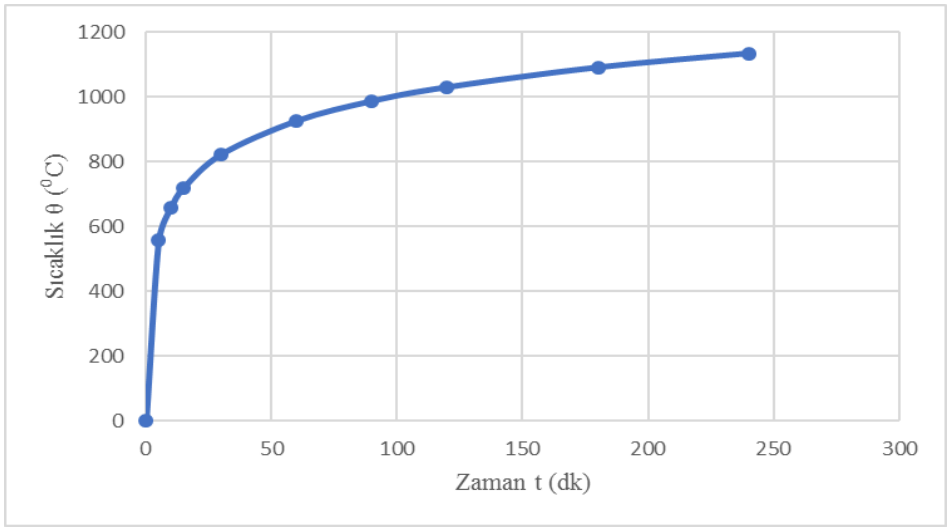

Şekil 2: ISO-834 standart yangın eğrisi 


\section{Malzeme ve Yöntem}

\subsection{Numunelerin Üretimi}

CTB numunelerin hazırlanması amacıyla, çalışmada çimento olarak, CEM I tipi PÇ 42,5 Portland Çimentosu kullanılmıştır. CTB numunelerinde kullanılan kuru silis kumu dane boyutu 0.063-1.400 mm arasındadır. Beton numunelerde cam lif olarak, boyu $24 \mathrm{~mm}$, çapı ise $15 \mu \mathrm{m}$ lifler kullanılmıştır. Kullanılan cam life ait özellikler Tablo 1'de verilmiştir. CTB numunelerin üretimi esnasında, lif takviyesi ile birlikte artan su ihtiyacını karşılayabilmek amacıyla çimento ağırlığının \%1'i oranında süper akışkanlaştırıcı ve priz geciktirici katkı maddesi de kullanılmıștır (Ali 2017). Çalışmada kullanılan cam lifi AR cam lifidir. AR tipi cam lifinde alkali zirkonyum silikatların alkali dayanımlı camların karışımı kullanılmaktadır. Çalışmada CTB numuneler prekast cephe kaplaması üretimi gerçekleştiren Bursa Grand Prekast firmasında üretilmiştir.

Tablo 1: Kullanılan cam life ait özellikler

\begin{tabular}{|c|c|c|c|c|c|}
\hline $\begin{array}{c}\text { Lif } \\
\text { Çeşidi }\end{array}$ & $\begin{array}{c}\text { Lif Boyu } \\
(\mathbf{m m})\end{array}$ & $\begin{array}{c}\text { Lif Çapı } \\
(\boldsymbol{\mu m})\end{array}$ & $\begin{array}{c}\text { Özgül Ağırlık } \\
\left(\mathbf{m g} / \mathbf{m}^{\mathbf{3}}\right)\end{array}$ & $\begin{array}{c}\text { Elastisite Modülü } \\
(\mathbf{M P a})\end{array}$ & Çekme Mukavemeti (MPa) \\
\hline Cam & 24 & 15 & 2,68 & 72000 & 1700 \\
\hline
\end{tabular}

CTB numuneler TS 802 (2009)'de belirtilen beton karıșım esaslarına göre hazırlanmıștır. CTB numuneler silis kumubeyaz çimento karışımı özel granülometrideki harmanın, alkaliye dayanıklı ithal cam elyafı ve polymer katkılı olarak, özel kalıplara püskürtme suretiyle dökülmesiyle üretilmiştir. AR-cam elyafı ve polymer, üretim yapılan firma tarafından temin edilmiştir. Numunelerin üretim için, dane boyutu $0.063-1.400 \mathrm{~mm}$ arasında olan $\left(630 \mathrm{~kg} / \mathrm{m}^{3}\right) \mathrm{kuru}$ silis $\mathrm{kumu}$ alınmıştır ve $\left(700 \mathrm{~kg} / \mathrm{m}^{3}\right)$ CEM I tipi PÇ 42,5 Portland Çimentosu eklenmiştir ve $\left(420 \mathrm{~kg} / \mathrm{m}^{3}\right)$ su eklenmiştir ve yeterli miktarda karıștırılmıștır. CTB'lerin üretilmesinde su/çimento oranı 0.6 olarak seçilmiștir. Literatürde CTB üretiminde kullanılacak olan S/Ç oranları ile ilgili değişik değerler söz konusudur. Örneğin Yaprak vd. (2004) 0.53, Y1ldız vd. (2011) 0.60 değerlerini kullanmışlardır. Bu çalışmada ise CTB imalatçısının mamul üretiminde kullandığı S/Ç oranı kullanılmıștır.

Hazırlanacak olan beton numunelerin üretimi sırasında, karışıma $0,5,10,15$ ve $20 \mathrm{~kg} / \mathrm{m}^{3}$ oranlarında cam lif ilave edilmiştir, lif takviyesi ile birlikte artan su ihtiyacını karşılayabilmek amacıyla çimento ağırlı̆̆ının \%1'i oranında süper akışkanlaştırıcı ve priz geciktirici katkı maddesi de kullanılmıştır ve iyice karıştırılmıştır. Püskürtme el tabancası ile yapıldığı ve püskürtülecek olan malzeme karıșımı kullanıcı tarafından ayarlanacağ araştırmacılar tarafından yerinde kontrol edilerek imalat yapılmıştır. Üretilen beton yağlanmış, TS EN 12390-3 (2003) ve TS EN 12390-6 (2002) standartlarına göre Ø15/30 cm silindir ve 4x4x16 cm prizma kalıplara yerleştirilmiştir (Şekil 3). Her bir beton karışımından; 30 adet silindir ve 30 adet prizma numuneleri üretilmiştir. Beş farklı yangın süresi için 150 adet silindir ve 150 adet prizma olmak üzere toplam 300 adet numune üretilmiştir.

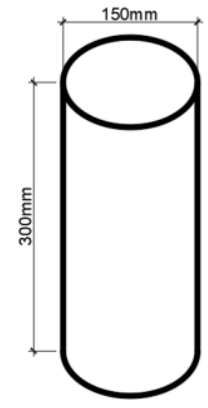

SíLINDIR Ø150/300 mm

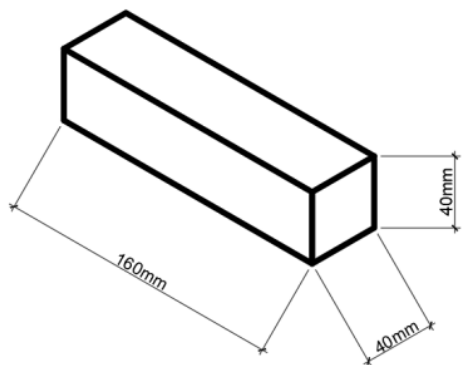

PRIZMA $40 \times 40 \times 160 \mathrm{~mm}$

Şekil 3: Üretilen numunelerin şekil özellikleri

CTB beton bileşiği kalıplara üç tabaka halinde dökülmüştür her bir tabaka iyi sıkıştırılmıştır. 24 saat sonunda kalıptan çıkarılan CTB numuneler 28 gün boyunca $20 \pm 2{ }^{\circ} \mathrm{C}$ kirece doygun suda kür edilmiştir (Şekil 4). Cam lif miktarı artıkça taze betonun işlenebilirliği azalmıştır. Özellikle $15 \mathrm{~kg} / \mathrm{m}^{3}$ lif oranından sonra taze betonun işlenebilirliği önemli ölçüde azalmıştır. 


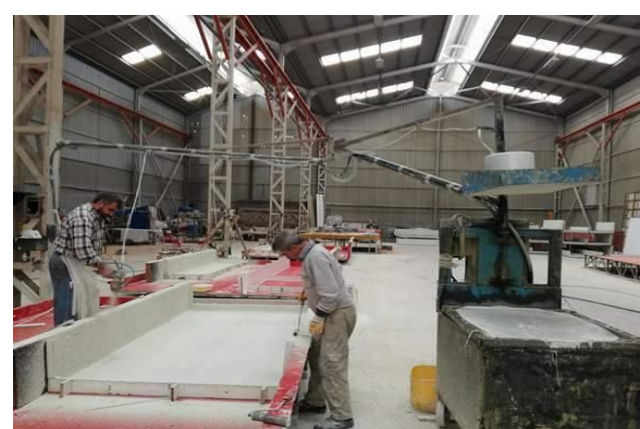

(a)

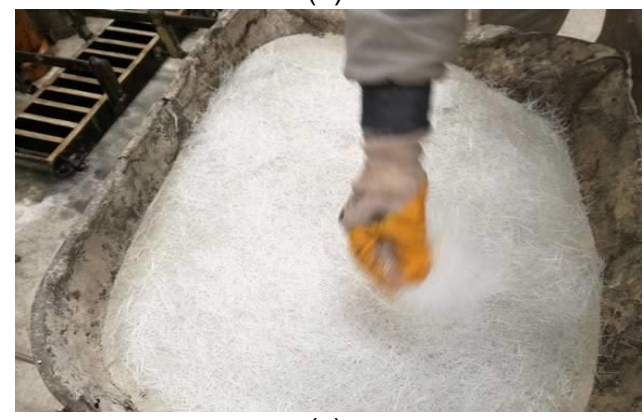

(c)

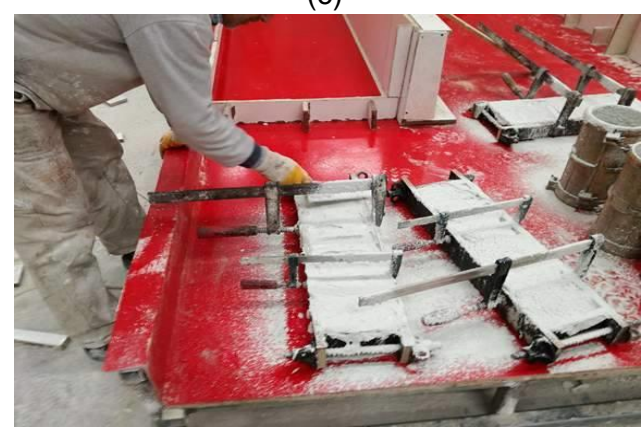

(e)

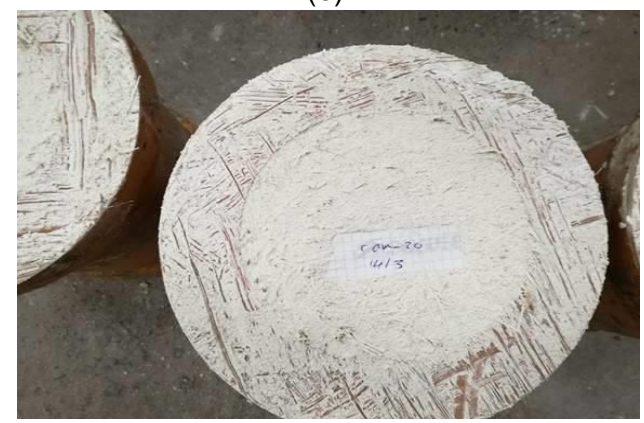

(g)

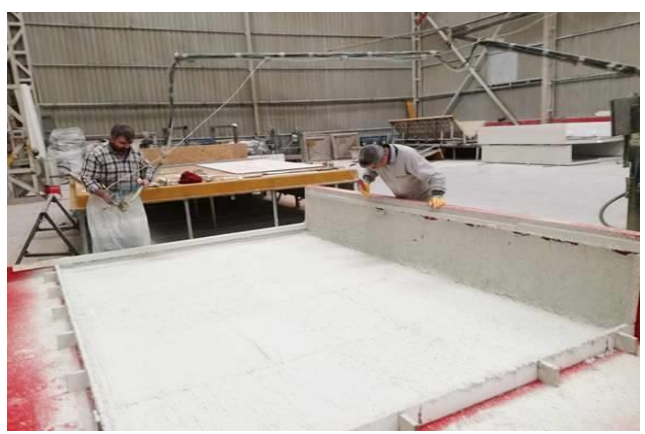

(b)

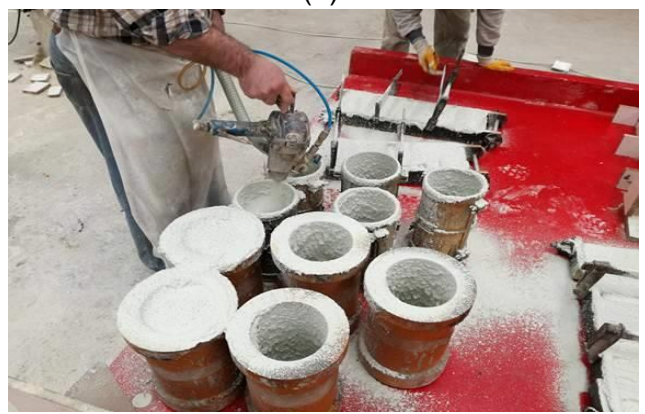

(d)

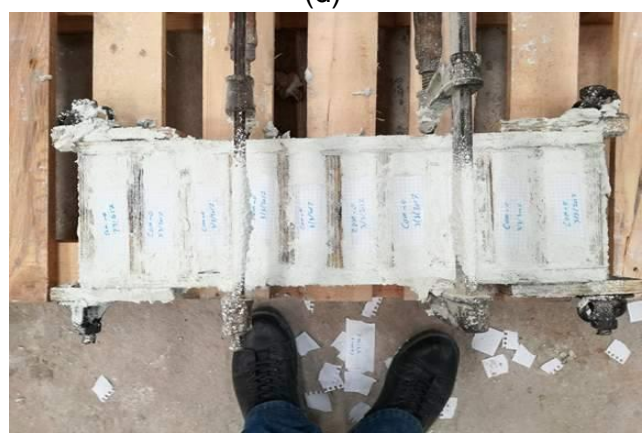

(f)

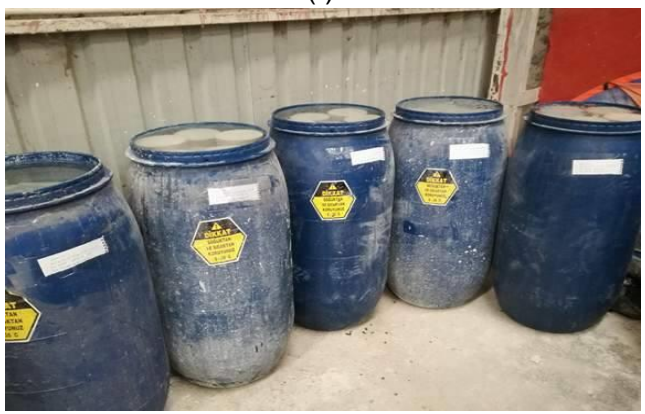

(h)

Şekil 4: Numunelerin üretim aşamaları

Numuneler ilk olarak Selçuk Üniversitesi Teknik Bilimler Meslek Yüksek Okulu İnşaat laboratuvarına götürülerek yangın deneylerine tabi tutulmuştur. Daha sonra Selçuk Üniversitesi İnşaat Mühendisliği Bölümü Yapı ve Deprem laboratuvarına getirilerek numuneler üzerinde, basınç dayanımı deneyi, çekme deneyleri (yarmada çekme, eğilmede çekme tek ve çift noktadan) deneyleri yapılmıştır.

Bu çalışmada; cam lifi dozlarını değiştirilerek 10 farklı CTB numunesi üretilmiştir. Numune kodlarının belirlenirken kullanılan liflerin oranları ve numunelerin şekilleri esas alınmıştır. Üretilen numunelerin kodları ve karışımlardaki lif oranı Tablo 2'de verilmiştir. Tablodan görüleceği gibi toplam numune sayıs1 300'dür. 
Tablo 2: Deney için üretilen CTB numunelerin kodları

\begin{tabular}{|c|c|c|c|c|}
\hline No & $\begin{array}{c}\text { Numune } \\
\text { Kodu }\end{array}$ & $\begin{array}{c}\text { Numune } \\
\text { Cam oranları } \\
\left(\mathbf{k g} / \mathbf{m}^{\mathbf{3}}\right)\end{array}$ & $\begin{array}{c}\text { Numune } \\
\text { Geometrisi }\end{array}$ & $\begin{array}{c}\text { Numune } \\
\text { Sayısı }\end{array}$ \\
\hline 1 & Cam-0S & 0 & Silindir & 30 \\
\hline 2 & Cam-5S & 5 & Silindir & 30 \\
\hline 3 & Cam-10S & 10 & Silindir & 30 \\
\hline 4 & Cam-15S & 15 & Silindir & 30 \\
\hline 5 & Cam-20S & 20 & Silindir & 30 \\
\hline 6 & Cam-0P & 0 & Prizmatik & 30 \\
\hline 7 & Cam-5P & 5 & Prizmatik & 30 \\
\hline 8 & Cam-10P & 10 & Prizmatik & 30 \\
\hline 9 & Cam-15P & 15 & Prizmatik & 30 \\
\hline 10 & Cam-20P & 20 & Prizmatik & 30 \\
\hline
\end{tabular}

Hazırlanan CTB numunelerin karışım oranları Tablo 3'de verilmiştir. Karışım oranlarından görüleceği üzere beton içeriğinde tek değişken cam lif $\left(\mathrm{kg} / \mathrm{m}^{3}\right)$ oranlardır.

Tablo 3: Deney için üretilen CTB numunelere ait karışım oranları ( $1 \mathrm{~m}^{3}$ beton için)

\begin{tabular}{|c|c|c|c|c|c|c|c|c|}
\hline No & $\begin{array}{c}\text { Numune } \\
\text { Kodu }\end{array}$ & $\begin{array}{c}\text { Numune } \\
\text { Geometrisi }\end{array}$ & $\begin{array}{c}\text { Çimento } \\
(\mathbf{k g})\end{array}$ & $\begin{array}{c}\text { Su } \\
(\mathbf{k g})\end{array}$ & $\begin{array}{c}\text { Kuru } \\
\text { Silis } \\
\text { Kumu } \\
(\mathbf{k g})\end{array}$ & $\begin{array}{c}\text { Cam Lif } \\
\text { Oranları } \\
\left(\mathbf{k g} / \mathbf{m}^{\mathbf{3}}\right)\end{array}$ & $\begin{array}{c}\text { Numune } \\
\text { Adedi }\end{array}$ & $\begin{array}{c}\text { Katkının } \\
\text { Çimentoya } \\
\text { Ağırlıça } \\
\text { Oranı }(\boldsymbol{\%})\end{array}$ \\
\hline 1 & Cam-0S & Silindir & 700 & 420 & 630 & 0 & 30 & 1 \\
\hline 2 & Cam-5S & Silindir & 700 & 420 & 630 & 5 & 30 & 1 \\
\hline 3 & Cam-10S & Silindir & 700 & 420 & 630 & 10 & 30 & 1 \\
\hline 4 & Cam-15S & Silindir & 700 & 420 & 630 & 15 & 30 & 1 \\
\hline 5 & Cam-20S & Silindir & 700 & 420 & 630 & 20 & 30 & 1 \\
\hline 6 & Cam-0P & Prizmatik & 700 & 420 & 630 & 0 & 30 & 1 \\
\hline 7 & Cam-5P & Prizmatik & 700 & 420 & 630 & 5 & 30 & \\
\hline 8 & Cam-10P & Prizmatik & 700 & 420 & 630 & 10 & 30 & \\
\hline 9 & Cam-15P & Prizmatik & 700 & 420 & 630 & 15 & 30 & 1 \\
\hline 10 & Cam-20P & Prizmatik & 700 & 420 & 630 & 20 & 30 & 1 \\
\hline
\end{tabular}

Farklı oranlardaki cam lif takviyesinin betonun mekanik davranışları üzerindeki etkilerini belirleyebilmek amacıyla, hazırlanın CTB numunelerin üzerinde yangın deneyi öncesinde ve yangın deneyi sonrasında olmak üzere basınç dayanımı deneyi, çekme deneyleri (yarmada çekme), çekme deneyleri (eğilmede çekme) ve çekme deneyleri (eğilme deneyi (Çift Noktadan)) gerçekleştirilmiştir. Yangın testleri ise TS EN 1363-2 (2012)’ye uygun olarak yapılmıştır.

\subsection{Yangın deneyleri}

Beton numunelerin yangın dayanımını tespiti için, Selçuk Üniversitesi Teknik Bilimler Meslek Yüksek Okulu İnşaat Programı Laboratuvarında hazırlanan yangın odası kullanılmıştır. Deneylerde yangınların gerçekleştirileceği yangın odası, ana taşıyıcı duvarı yığma tuğlası olan ve iç kısımları ateş tuğlasından örülmüş ve dış yüzeyi sıvandıktan sonra taş yünü ile yangın yalıtımı yapılmış olan yangın odası esasen doğal bir yangını modellemek için tasarlanmıştır. Bu odada oksijen girişiyle yangının sürekliliğini ve duman tahliyesini sağlamak içinde ayrıca üst kısmına saç baca yapılmıştır. Baca düzenli olarak ortama oksijen girişini sağladığından dolayı odaya ayrıca pencere boşluğu açmaya gerek duyulmamıştır. Yangın odası kapısı için EN 1363-1 (2012) ve EN 1634-4 (2009) standartlarına uygun özel bir firmaya ait bir yangın kapısı kullanılmıştır.

Doğal yangını oluşturmak için kullanılacak yakıt, ahşap artıkları, talaş, kaput, bez gibi günlük hayatta sıkça karşılaşılan yanıcı malzemelerdir. Numuneler ızgara planlı bir şekilde odaya yerleştirilerek homojen bir şekilde yakıt ve yanıcı malzemeler aralara dağıtılmıştır. Bir malzemenin yanıcılık sınıfları için belirleyici ölçüt olan 0, 30, 60, 90 ve 120 dakika yangın süresi bu çalışma içinde bir parametre olarak belirlenmiştir. Deney sürecinde iç ortam sıcaklığının zamanla değişimi kayıt altına alınmıştır. Numunelerin mümkün olduğunca eşit miktarda yangından zarar görmeleri için yangın odası içine numuneler yangın merkezine eşit uzaklıklarda dağıtılmışlardır. Numuneler soğuduktan sonra yangın odasından çıkarılarak laboratuvara alınmış ve yangın süresi ve dereceleri kayıt altına alınmıştır. Yangın sırasında termal kamera ile farklı görüntüler kayıt altına alınmış, deney sonunda ise numune yüzeyindeki değişimler hakkında değerlendirme yapılmıştır. Şekil 5'de yangın odası ile ilgili genel bilgiler verilmiştir. Şekil 6'da ise yangın öncesi ve sonrası ortam görselleri gösterilmiştir. 


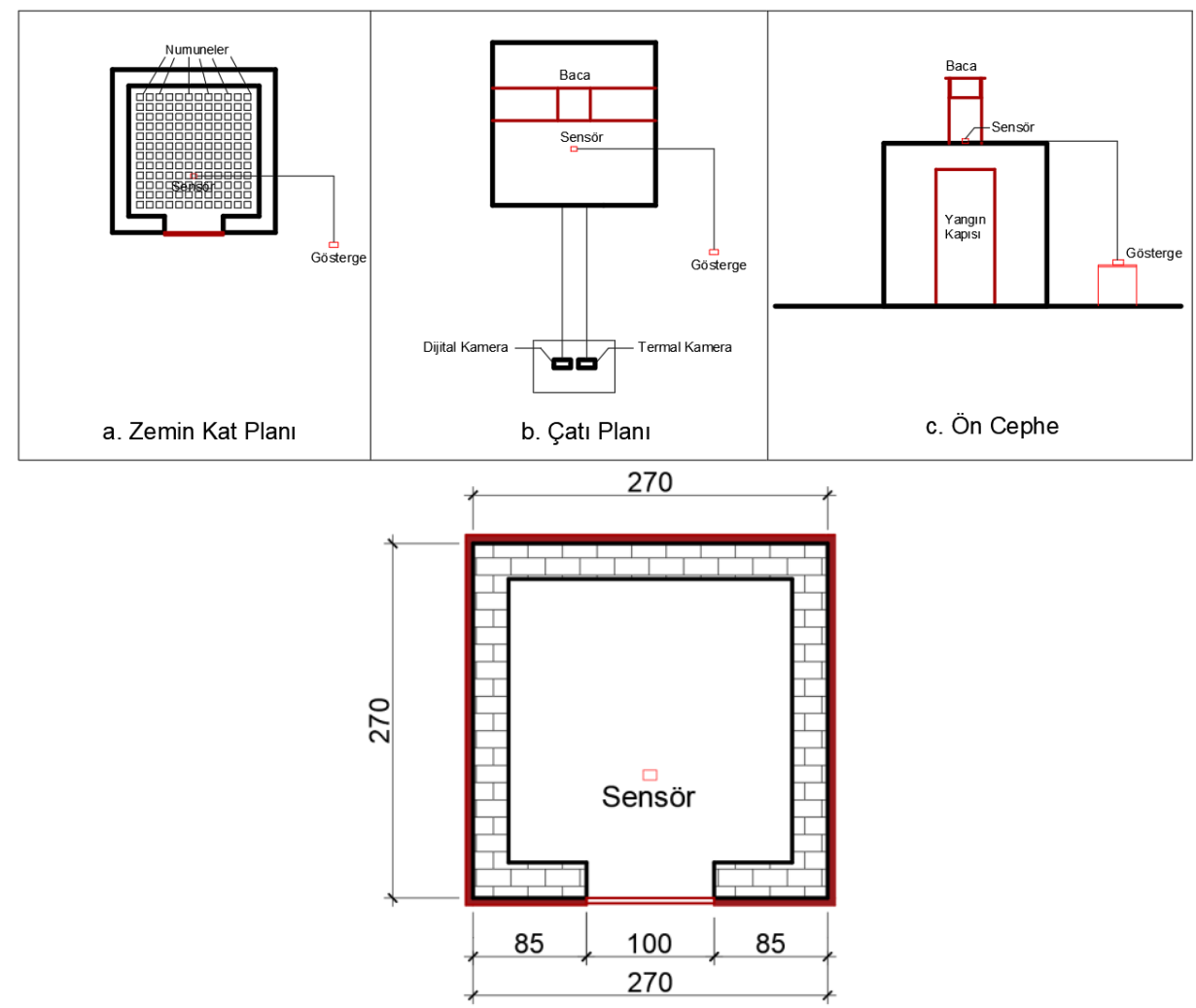

Şekil 5: Yangın odasının şekli ve deney düzeneği 


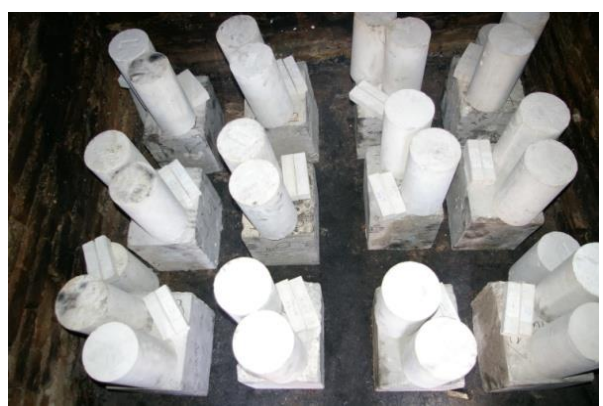

(a)

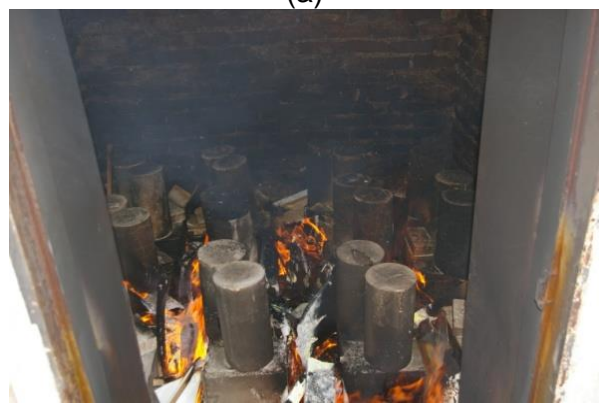

(c)

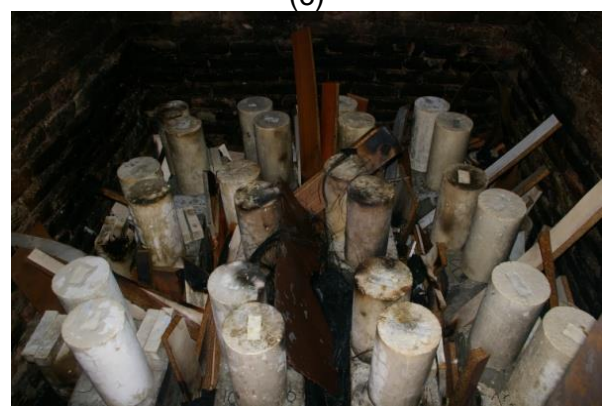

(e)

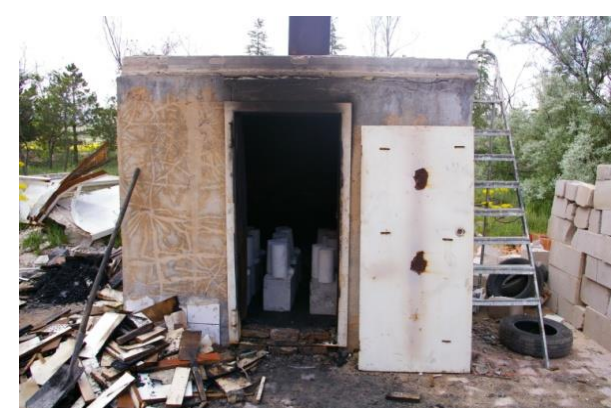

(b)

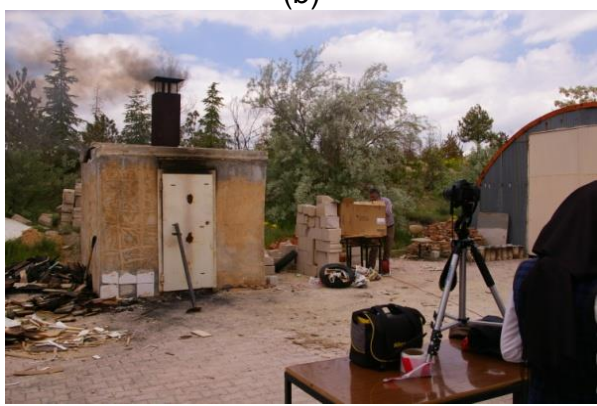

(d)

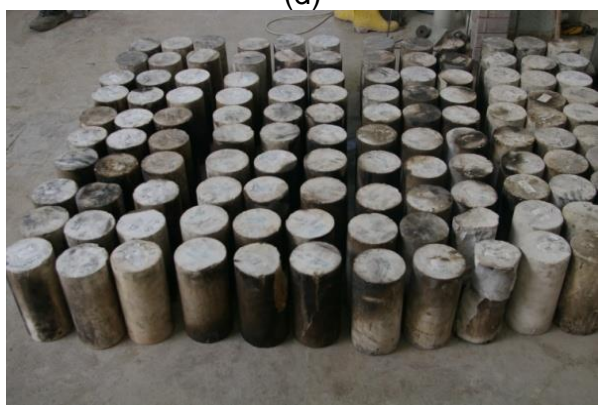

(f)

Șekil 6: Yangın odası ve deney numuneleri

Bu çalışmada da, deneysel çalışmalar için bir test düzeneği hazırlanmış ve doğal yangını betimlemek üzere 4 ayrı yangın süresi (30 dk, 60 dk, 90 dk ve $120 \mathrm{dk}$ ) dikkate alınmıştır. Yangın deneyinin sıcaklık-zaman eğrisi Şekil 7'de gösterilmiştir.

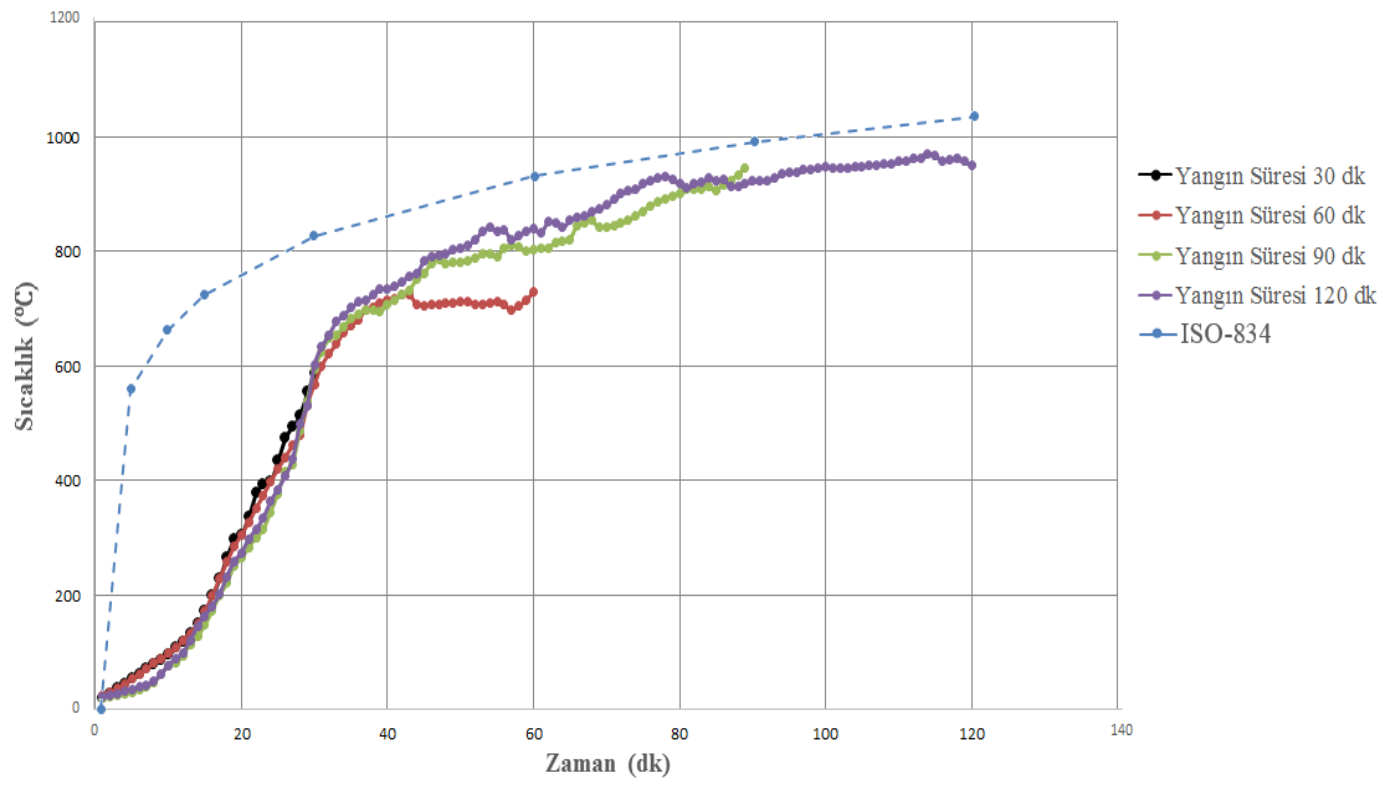

Șekil 7: Yangın deneyin sıcaklık-zaman eğrisi 
Aynı zamanda deney esnasında infrared termografi ile yangın odasından termal görüntüler alınarak deney düzeneğinde kullanılan termokupl (termacouble) alınan verilerle karşılaştırmaları yapılmıştır. Yangın deney esnasında deney odasının, numunelerin ve termokupl (termacouble) sarkıtılmış ısısının alınan termal kamera görüntüsü Şekil 8'de verilmiştir. Şekil 6'dan görüleceği gibi yangın doğal yöntemlerle çıkarıldığı için ISO-834 eğrisi tam olarak elde edilememiştir.

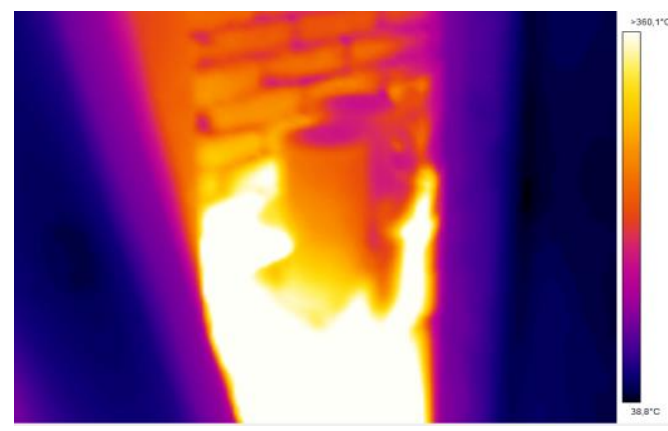

Şekil 8: Yangın devam ederken alınan termal kamera görüntüsü

Çeşitli sürelerde yanmış 240 ve yanmamış 60 toplamda 300 adet CTB numunelerinin mekanik özellikleri Selçuk Üniversitesi İnşaat Mühendisliği Bölümü Yapı ve Deprem Laboratuvarında deneysel olarak test edilmiştir. 300 adet numunede; basınç dayanımı, çekme dayanımı (yarmada çekme-eğilmede çekme) bulunarak yangın süresinin CTB'ların mekanik özelliklerine olan etkisi incelenmiştir.

\subsection{Basınç ve çekme deneyleri}

Hazırlanan silindir numuneler üzerinde, Selçuk Üniversitesi İnşaat Mühendisliği Bölümü Yapı ve Deprem Laboratuvarında, yangın deneyi öncesinde ve yangın deneyi sonrasında, TS EN 12390-3 (2003)'e uygun olarak basınç ve çekme testleri yapılmıştır (Şekil 8). Basınç ve yarmada çekme testlerinde 200 ton kapasiteli ALFA TESTING GAGE (B001/EKD-PC) cihazı kullanılmış ve yükleme hızı $3 \mathrm{kN} / \mathrm{sn}$ olacak şekilde sabit tutulmuştur. Yarma testi için Ø15/30 cm silindir numuneler kullanılmıştır. Deney yöntemi olarak TS EN-12390-6 (2002) ve ASTM C 496 (2011)'da belirtildiği ve Şekil 9'da görüldüğü gibi numune, deney presinin üzerine numune ekseni presin alt tablasına paralel olacak şekilde yatırılmıştır. Uygulanan basınç yükü altında numunelerde poisson etkisi yük seksenine dik doğrultuda çekme gerilmeleri oluşmuş ve bu nedenle numuneler çekmeden kırılmıştır. Silindir numunenin kırılma şekli ortadan ikiye yarılma şekliden gerçekleşmiştir.

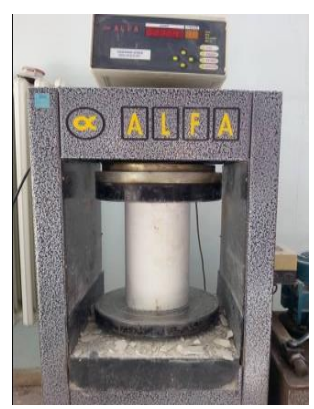

a) Basınç

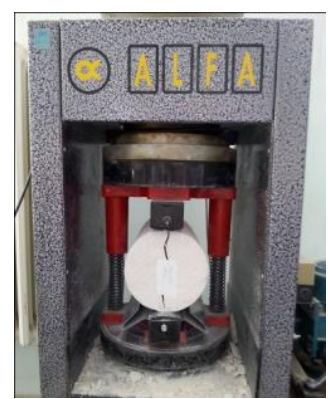

b)Yarmada çekme dayanımı elde edilmesi $\left(\sigma^{\prime}=\frac{2 P}{\pi * L * D}\right) *$

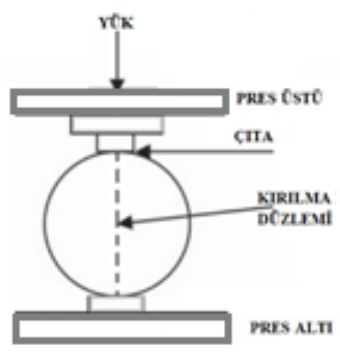

exs A.n

\section{Şekil 9: Yangın sonrası numunelerin basınç ve yarmada çekme testleri ( ${ }^{*} D e n k l e m d e ~ P$ kırılma sırasında ölçülen basınç yükü, L silindirin yüksekliği $D$ ise silindirin çapını göstermektedir)}

CTB numunelerinin eğilmede çekme dayanımlarını elde edebilmek içim tek ve çift noktadan eğilmede çekme testleri ELE Autotest 300 ton kapasite cihazı altında gerçekleştirilmiştir. TS 3285 (1979) ve ASTM C 293 (1994)'ye göre beton prizmatik kirişlerin oturduğu mesnetlerin arasındaki mesafenin orta noktasından yüklenmesi ile tek noktadan eğilme deneyi, TS 3284 (1979) ve ASTM C 78 (1994)'e göre ise beton kirişin oturtulduğu mesnetlerden L/3 uzaklıktaki iki noktadan yüklenmesi durumunda ise çift noktadan eğilmede deneyi gerçekleştirilmiştir. Şekil 10'da numunelerin ve deney düzeneğinin şematik çizimleri verilmiştir. Amaç nihai yükün ölçülmesi olduğu için deneyler yük kontrollü olarak gerçekleştirilmiştir. Numune açıklığından herhangi bir deplasman ölçümü yapılmamıştır. Deney esnasında uygulanan yükleme hızı $3 \mathrm{kN} / \mathrm{sn}$ olacak şekilde sabit tutulmuştur. 

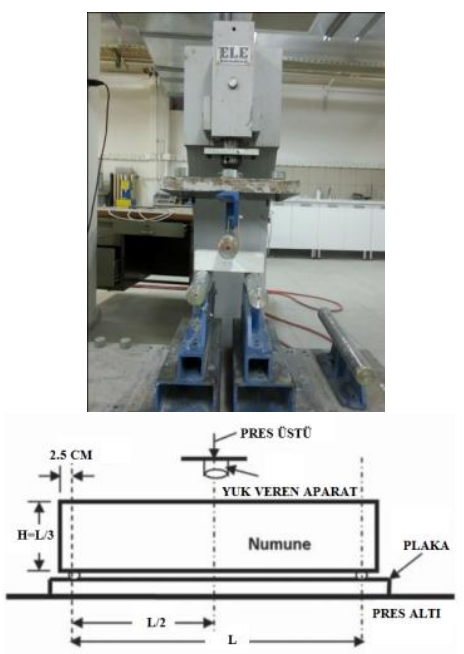

a) Tek noktada eğilmede çekme testi

$$
\left(\sigma^{\prime}=\frac{3 P L}{2 H^{3}}\right)^{*}
$$

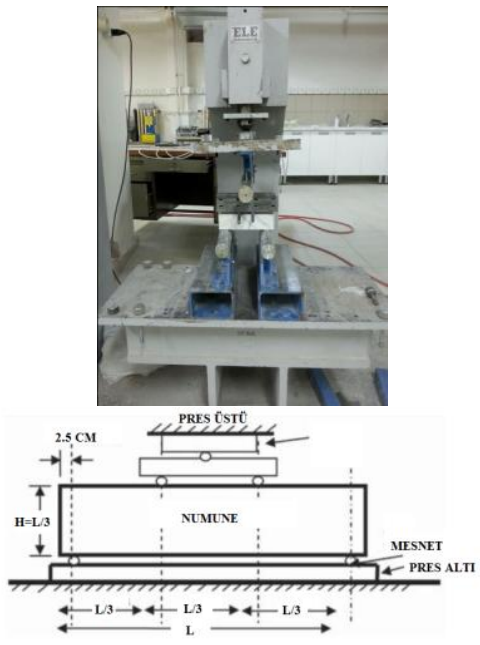

b) Çift noktada eğilmede çekme testi

$$
\left(o^{\prime}=\frac{P L}{H^{3}}\right) *
$$

Șekil 10: Yangın sonrası numunelerin eğilmede çekme testleri ( ${ }^{*}$ Denklemlerde $P$ kırılma sırasında ölçülen basınç yükü, L prizmanın mesnetler arasında açıklık mesafesini, b ve d ise prizma boyutlarını göstermektedir. Şematik çizimler Çivici ve Eren (2004)'den uyarlanmıştır)

CTB numunelerinin çekme dayanımları hem silindir yarma deneyi ile ve hem de tek ve çift yük etkisi altında eğilmede çekme deneyleri ile elde edilmiştir. Burada amaç malzemenin çekme dayanımını farklı deney yöntemleri ile elde edip karşılaştırma yapmaktır.

\subsection{Deney sonuçları}

Çalışmalar sırasında hazırlanan CTB numunelerin üzerinde yangın deneyi öncesinde ve yangın deneyi sonrasında olmak üzere yapılan deneylerin sonuçları bu bölümde verilmiştir. Numunelere ait deneysel çalışmalarda elde edilen basınç, yarmada çekme, tek ve çift noktadan eğilmede çekme dayanımı değerleri sırasıyla Tablo 4, Tablo 5, Tablo 6 ve Tablo 7' de verilmiştir.

\begin{tabular}{|c|c|c|c|c|c|c|}
\hline \multirow[t]{2}{*}{ No } & \multirow{2}{*}{$\begin{array}{l}\text { Numunelerin } \\
\text { Kodu }\end{array}$} & \multirow{2}{*}{$\begin{array}{c}28 \text { Gün Basınç } \\
\text { Dayanımı } \\
\text { (Yangından Önce) } \\
\text { (Mpa) f f-glass-referans }\end{array}$} & \multicolumn{4}{|c|}{$\begin{array}{c}28 \text { Gün Basınç Dayanımı (Yangından Sonra) } \\
\text { (Mpa) } f_{\text {c-glass-yanmış }}\end{array}$} \\
\hline & & & $\begin{array}{l}\text { Yangın Süresi } \\
\mathbf{3 0 ~ d k}\end{array}$ & $\begin{array}{l}\text { Yangın Süresi } \\
60 \mathrm{dk}\end{array}$ & $\begin{array}{l}\text { Yangın Süresi } \\
90 \mathrm{dk}\end{array}$ & $\begin{array}{l}\text { Yangın Süresi } \\
120 \mathrm{dk}\end{array}$ \\
\hline \multirow{3}{*}{1} & Cam-0S-1 & 95.3 & 83.3 & 83.6 & 82.1 & 61.8 \\
\hline & Cam-0S-2 & 74.4 & 65.5 & 76.5 & 72.6 & 62.2 \\
\hline & Cam-0S-3 & 84.9 & 85.3 & 85.0 & 76.7 & 62.0 \\
\hline \multirow{3}{*}{2} & Cam-5S-1 & 75.0 & 77.4 & 83.7 & 77.7 & 39.0 \\
\hline & Cam-5S-2 & 62.5 & 53.0 & 53.8 & 41.0 & 50.6 \\
\hline & Cam-5S-3 & 61.5 & 75.7 & 73.1 & 47.0 & 78.3 \\
\hline \multirow{3}{*}{3} & Cam-10S-1 & 59.1 & 95.0 & 63.9 & 58.3 & 70.0 \\
\hline & Cam-10S-2 & 85.7 & 58.7 & 62.3 & 32.0 & 82.1 \\
\hline & Cam-10S-3 & 74.5 & 59.7 & 79.8 & 78.7 & 62.5 \\
\hline \multirow{3}{*}{4} & Cam-15S-1 & 77.0 & 74.7 & 55.8 & 69.5 & 74.0 \\
\hline & Cam-15S-2 & 66.0 & 87.4 & 48.5 & 67.4 & 97.6 \\
\hline & Cam-15S-3 & 88.0 & 83.3 & 74.2 & 75.4 & 55.8 \\
\hline \multirow{3}{*}{5} & Cam-20S-1 & 68.6 & 74.4 & 75.0 & 84.4 & 76.8 \\
\hline & Cam-20S-2 & 68.6 & 49.7 & 65.3 & 97.9 & 73.1 \\
\hline & Cam-20S-3 & 81.5 & 84.9 & 74.9 & 60.5 & 54.7 \\
\hline
\end{tabular}

Tablo 4: Silindir numunelere ait basınç dayanımı değerleri 
Tablo 5: Silindir numunelere ait yarmada çekme dayanımı değerleri

\begin{tabular}{|c|c|c|c|c|c|c|}
\hline \multirow[t]{2}{*}{ No } & \multirow{2}{*}{$\begin{array}{l}\text { Numunelerin } \\
\text { Kodu }\end{array}$} & \multirow{2}{*}{$\begin{array}{c}28 \text { Gün Yarmada } \\
\text { Çekme Dayanımı } \\
\text { (Yangından Önce) } \\
\text { (Mpa) fct-glass- } \\
\text { referans } \\
\end{array}$} & \multicolumn{4}{|c|}{$\begin{array}{c}28 \text { Gün Yarmada Çekme Dayanımı (Yangından Sonra) } \\
\text { (Mpa) fct-glass-yanmış }\end{array}$} \\
\hline & & & $\begin{array}{l}\text { Yangın Süresi } \\
30 \mathbf{d k}\end{array}$ & $\begin{array}{l}\text { Yangin Süresi } \\
60 \mathrm{dk}\end{array}$ & $\begin{array}{l}\text { Yangin Süresi } \\
90 \mathrm{dk}\end{array}$ & $\begin{array}{l}\text { Yangin Süresi } \\
120 \mathrm{dk}\end{array}$ \\
\hline \multirow{3}{*}{1} & Cam 0S-1 & 17.2 & 11.0 & 17.6 & 9.5 & 19.3 \\
\hline & Cam 0S-2 & 29.8 & 17.0 & 12.0 & 30.5 & 22.1 \\
\hline & Cam 0S-3 & 14.6 & 15.5 & 20.5 & 14.6 & $-*$ \\
\hline \multirow{3}{*}{2} & Cam 5S-1 & 19.4 & 12.5 & 19.8 & 17.2 & 24.6 \\
\hline & Cam 5S-2 & 24.3 & 17.0 & 24.1 & 24.5 & 13.6 \\
\hline & Cam 5S-3 & 18.4 & 12.0 & 14.5 & 15.2 & $-*$ \\
\hline \multirow{3}{*}{3} & Cam 10S-1 & 25.0 & 18.8 & 25.3 & 24.3 & 24.0 \\
\hline & Cam 10S-2 & 27.1 & 11.5 & 19.0 & 17.5 & 11.2 \\
\hline & Cam 10S-3 & 22.5 & 17.5 & 15.5 & 17.2 & 13.8 \\
\hline \multirow{3}{*}{4} & Cam 15S-1 & 31.7 & 16.20 & 18.0 & 18.2 & 18.2 \\
\hline & Cam 15S-2 & 23.9 & 26.0 & 16.0 & 23.6 & 12.0 \\
\hline & Cam 15S-3 & 33.2 & 12.00 & 15.0 & 20.0 & 14.5 \\
\hline \multirow{3}{*}{5} & Cam 20S-1 & 29.8 & 17.70 & 28.8 & 24.5 & 26.0 \\
\hline & Cam 20S-2 & 28.5 & 12.90 & 21.7 & 20.5 & 22.3 \\
\hline & Cam 20S-3 & 22.8 & 17.20 & 17.5 & 16.6 & 22.0 \\
\hline
\end{tabular}

*: Yangın testleri sırasına kesit kaybı çok olan ve mekanik testlere alınamayan numuneler

Tablo 6: Prizmatik numunelere ait tek noktadan eğilmede çekme dayanımı değerleri

\begin{tabular}{|c|c|c|c|c|c|c|}
\hline \multirow[t]{2}{*}{ No } & \multirow{2}{*}{$\begin{array}{l}\text { Numunelerin } \\
\text { Kodu }\end{array}$} & \multirow{2}{*}{$\begin{array}{l}28 \text { Gün Eğilmede } \\
\text { Çekme Dayanımı } \\
\text { (Yangından Önce) } \\
\text { (Mpa) f ftf1-glass-referans }\end{array}$} & \multicolumn{4}{|c|}{$\begin{array}{l}28 \text { Gün Eğilmede Çekme Dayanımı (Yangından Sonra) } \\
\text { (Mpa) f ftf1-glass-yanmış }\end{array}$} \\
\hline & & & $\begin{array}{c}\text { Yangın } \\
\text { Süresi } 30 \\
\text { dk }\end{array}$ & $\begin{array}{c}\text { Yangın } \\
\text { Süresi } 60 \\
\text { dk }\end{array}$ & $\begin{array}{c}\text { Yangın } \\
\text { Süresi } 90 \\
\text { dk }\end{array}$ & $\begin{array}{c}\text { Yangın Süresi } \\
120 \mathrm{dk}\end{array}$ \\
\hline \multirow{3}{*}{1} & Cam-0P-1 & 28.5 & 16.8 & 17.2 & 28.5 & 23.8 \\
\hline & Cam-0P-2 & 22.8 & 20.6 & 22.3 & 17.6 & 19.6 \\
\hline & Cam-0P-3 & 28.5 & 21.2 & 24.6 & 21.2 & 22.7 \\
\hline \multirow{3}{*}{2} & Cam-5P-1 & 27.8 & 37.4 & 27.7 & 31.8 & 27.1 \\
\hline & Cam-5P-2 & 32.9 & 42.3 & 22.3 & 27.3 & 35.2 \\
\hline & Cam-5P-3 & 26.5 & 29.3 & 21.2 & 23.9 & 36.4 \\
\hline \multirow{3}{*}{3} & Cam-10P-1 & 36.9 & 32.3 & 24.0 & 27.9 & 31.8 \\
\hline & Cam-10P-2 & 35.5 & 22.9 & 44.3 & 16.5 & 38.3 \\
\hline & Cam-10P-3 & 33.5 & 36.3 & 20.5 & 29.4 & 31.2 \\
\hline \multirow{3}{*}{4} & Cam-15P-1 & 39.1 & 5.18 & 32.9 & 44.6 & 24.5 \\
\hline & Cam-15P-2 & 36.9 & 37.7 & 24.9 & 44.1 & 22.7 \\
\hline & Cam-15P-3 & 41.4 & 40.5 & 21.9 & 27.3 & 39.0 \\
\hline \multirow{3}{*}{5} & Cam-20P-1 & 36.8 & 32.8 & 39.4 & 29.4 & 17.2 \\
\hline & Cam-20P-2 & 37.0 & 39.5 & 38.0 & 26.5 & 15.7 \\
\hline & Cam-20P-3 & 33.0 & 35.3 & 34.0 & 35.3 & $-^{*}$ \\
\hline
\end{tabular}

\footnotetext{
*: Yangın testleri sırasına kesit kaybı çok olan ve mekanik testlere alınamayan numuneler
} 
Tablo 7: Prizmatik numunelere ait çift noktadan eğilmede çekme dayanımı değerleri

\begin{tabular}{|c|c|c|c|c|c|c|}
\hline \multirow[t]{2}{*}{ No } & \multirow{2}{*}{$\begin{array}{l}\text { Numunelerin } \\
\text { Kodu }\end{array}$} & \multirow{2}{*}{$\begin{array}{c}28 \text { Gün Eğilmede } \\
\text { Çekme (Çift } \\
\text { Noktadan) Dayanımı } \\
\text { (Yangından Önce) } \\
\text { (Mpa) f ftr2-glass-referans }\end{array}$} & \multicolumn{4}{|c|}{$\begin{array}{l}28 \text { Gün Eğilmede Çekme (Çift Noktadan) Dayanımı } \\
\text { (Yangından Sonra) (Mpa) f ftf2-glass-yanmış }\end{array}$} \\
\hline & & & $\begin{array}{c}\text { Yangın Süresi } \\
30 \mathrm{dk}\end{array}$ & $\begin{array}{c}\text { Yangin Süresi } \\
60 \mathrm{dk}\end{array}$ & $\begin{array}{c}\text { Yangin Süresi } \\
90 \mathrm{dk}\end{array}$ & $\begin{array}{c}\text { Yangin Süresi } \\
120 \mathrm{dk}\end{array}$ \\
\hline \multirow{3}{*}{1} & Cam-0P-1 & 27.0 & 27.6 & 27.9 & 28.7 & 27.4 \\
\hline & Cam-0P-2 & 39.2 & 28.7 & 28.8 & 24.9 & 23.4 \\
\hline & Cam-0P-3 & 28.5 & 25.4 & 19.8 & 25.4 & 23.4 \\
\hline \multirow{3}{*}{2} & Cam-5P-1 & 33.3 & 34.1 & 29.7 & 13.4 & 32.5 \\
\hline & Cam-5P-2 & 35.6 & 34.0 & 35.3 & 27.6 & 29.8 \\
\hline & Cam-5P-3 & 41.0 & 39.0 & 25.2 & 26.3 & 25.7 \\
\hline \multirow{3}{*}{3} & Cam-10P-1 & 34.4 & 49.2 & 30.8 & 16.5 & 29.8 \\
\hline & Cam-10P-2 & 42.2 & 45.9 & 32.6 & 24.2 & 42.7 \\
\hline & Cam-10P-3 & 38.3 & 38.6 & 31.7 & 33.5 & 35.9 \\
\hline \multirow{3}{*}{4} & Cam-15P-1 & 47.3 & 48.8 & 32.7 & 19.9 & 43.3 \\
\hline & Cam-15P-2 & 48.6 & 43.4 & 26.1 & 24.9 & 51.4 \\
\hline & Cam-15P-3 & 39.0 & 45.7 & 30.9 & 38.9 & 39.6 \\
\hline \multirow{3}{*}{5} & Cam-20P-1 & 33.9 & 42.8 & 31.2 & 24.7 & $-*$ \\
\hline & Cam-20P-2 & 44.4 & 36.2 & 40.7 & 34.4 & 20.7 \\
\hline & Cam-20P-3 & 36.3 & 47.9 & 29.3 & 29.8 & $-*$ \\
\hline
\end{tabular}

*: Yangın testleri sırasına kesit kaybı çok olan ve mekanik testlere alınamayan numuneler

\section{Sonuçlar}

$\mathrm{Bu}$ çalışmada, CTB numuneleri üzerinde farklı oranlardaki cam lif takviyesinin betonun mekanik özelliklerine etkisini belirlemek için yapılan, yangın deneyi öncesinde ve yangın deneyi sonrasında, elde edilen sonuçlarla ile ilgili sonuçlar yangın öncesi (yangın geçirmeyen) ve yangın sonrası (yangın geçiren) olmak üzere iki bölümde incelenebilir. Yangın öncesi ve yangın sonrası, CTB numunelerin dayanımlarının değişim değerlerinin, cam lif oranlarına (ağırlıkça) göre grafikleri Şekil 11 ve Şekil 12'de verilmiştir. Tablo 4-Tablo 7'de verilen değerlerin değişiminin daha rahat irdelenebilmesi için Şekil 11 ve Şekil 12 'de veriler normalleştirilmiştir.

Şekil 11 grafiğinden cam lif takviyesinin cam lif takviyesinin betonun basınç dayanımı üzerindeki olumsuz etkisinin olduğunu görülmüştür. Fakat cam lif miktarı artmasıyla bu olumsuz etkinin azaldığını görülmüştür. CTB'lerin takviyesiz numuneye göre cam lif oran $5 \mathrm{~kg} / \mathrm{m}^{3}$ 'de basınç dayanımı $\% 22$ düşmüş, $10 \mathrm{~kg} / \mathrm{m}^{3}$ ' de basınç dayanımı $\% 17$ düşmüş, 15 $\mathrm{kg} / \mathrm{m}^{3}$ 'de basınç dayanımı $\% 9$ düşmüş, $20 \mathrm{~kg} / \mathrm{m}^{3}$ 'de basınç dayanımı $\% 14$ bir düşüş meydana gelmiştir.

Aynı grafik üzerinden cam lif katkısının artması betonun çekme dayanımı (yarmada çekme) dayanımı üzerinde olumlu etkisi görülmüştür. CTB numunelerin takviyesiz numuneye göre cam lif oranı $5 \mathrm{~kg} / \mathrm{m}^{3}$ 'de (yarmada çekme) dayanımı $\% 1$ artmış, $10 \mathrm{~kg} / \mathrm{m}^{3}$ 'de (yarmada çekme) dayanımı \%21 artmış, $15 \mathrm{~kg} / \mathrm{m}^{3}$ 'de (yarmada çekme) dayanımı \%44 artmış, $20 \mathrm{~kg} / \mathrm{m}^{3}$ 'de (yarmada çekme) dayanımı \%32 bir artış meydana gelmiştir. Yapılan deneylerde beton içinde cam lifi kullanılması betonda, numunelerin kırılma sırasında gevrek davranış göstermesini engellediği de görülmüştür.

Cam lif oranının artması betonun tek noktadan eğilmede çekme dayanımı üzerindeki etkisi pozitif görülmüştür. CTB numune cam lif takviyesiz numuneye göre cam lif oran $15 \mathrm{~kg} / \mathrm{m}^{3}$ 'de (eğilmede çekme) dayanımı \%9 artmış, $10 \mathrm{~kg} / \mathrm{m}^{3}$ 'de (eğilmede çekme) dayanımı \%33 artmış, $15 \mathrm{~kg} / \mathrm{m}^{3}$ 'de (eğilmede çekme) dayanımı \%47 artmış, $20 \mathrm{~kg} / \mathrm{m}^{3}$ ' de (eğilmede çekme) dayanımı \%34 bir artış meydana gelmiştir.

Cam lif oranının artması betonun çift noktadan eğilmede çekme dayanımı üzerindeki olumlu etkisi yine ilgili şekilden görülmektedir. CTB numune takviyesiz numuneye göre cam lif oranı $5 \mathrm{~kg} / \mathrm{m}^{3}$ 'de (eğilmede çekme (Çift Noktadan)) dayanımı \%16 artmış, $10 \mathrm{~kg} / \mathrm{m}^{3}$ 'de (eğilmede çekme (Çift Noktadan)) dayanımı \%21 artmış, $15 \mathrm{~kg} / \mathrm{m}^{3}$ 'de (eğilmede çekme (Çift Noktadan)) dayanımı \%42 artmış, $20 \mathrm{~kg} / \mathrm{m}^{3}$ 'de (eğilmede çekme (Çift Noktadan)) dayanımı \%21 bir artış meydana gelmiştir. Tüm dayanım testlerine göre özellikle $15 \mathrm{~kg} / \mathrm{m}^{3}$ cam lifin optimum değer olduğu düşünülebilir. 


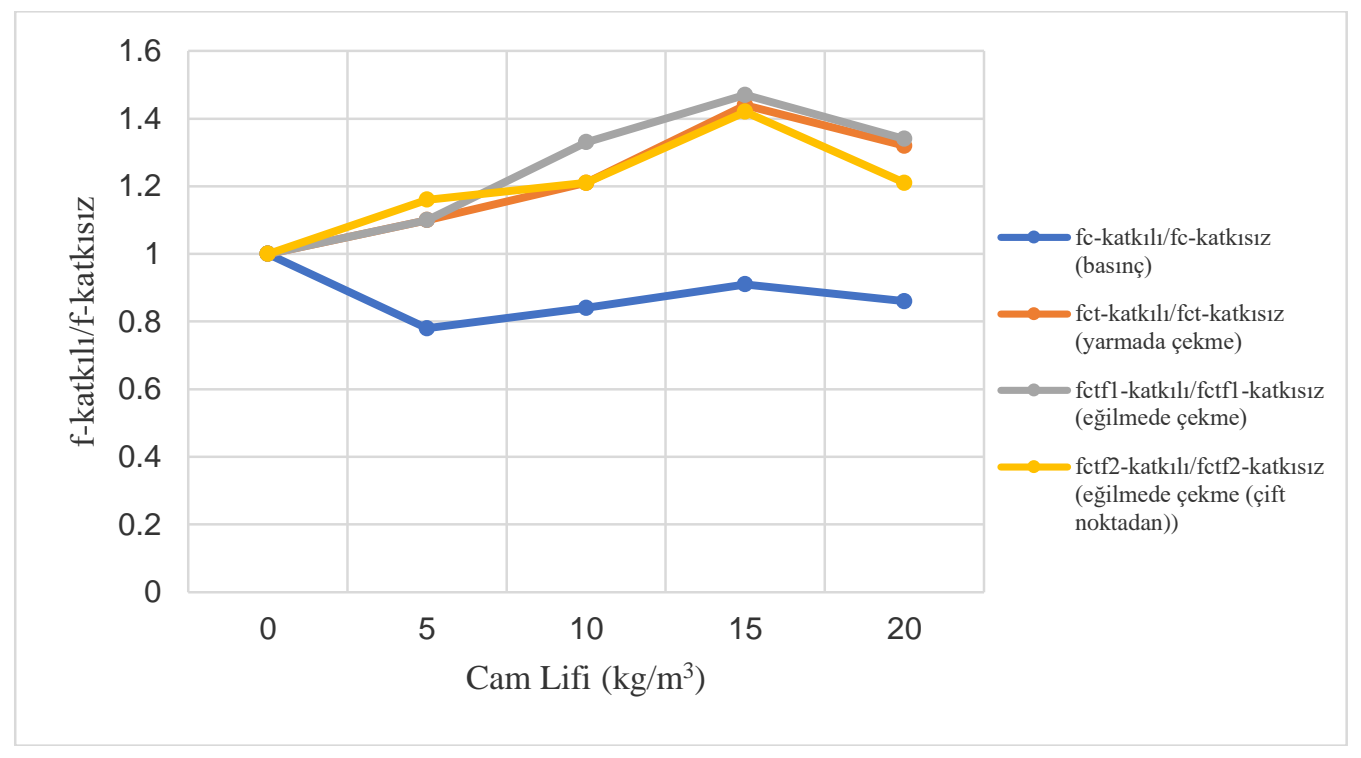

Șekil 11: Yangından önce dayanım değişim grafikleri

Yangın sonrası grafiklerde (Şekil 12) cam lif oranının artması yangın sonrasındaki basınç dayanım kaybını pozitif etkilemiştir. Cam lif oranı artıkça basınç dayanımında meydana gelen kayıp miktarı \%12'den \%0,4'e kadar düşmüştür. Cam lif oranının artması yangın sonrasındaki çekme dayanıma (yarmada çekme) kaybını negatif etkilemiştir. Cam lif oranı artıkça \%15 kayıp \%24 oranına çıkmıştır, bununla beraber cam lifi $15 \mathrm{~kg} / \mathrm{m}^{3} \mathrm{kayı} \% 41$ olarak en fazla görülmüştür. Yine cam lif oranının artmasının yangın sonrasındaki çekme dayanıma (eğilmede çekme (Çift Noktadan)) kaybını olumlu etkilemiştir. Cam lif oranı artıkça $\% 18$ kayıp $\% 17$ oranına düşmüş ve sadece $5 \mathrm{~kg} / \mathrm{m}^{3}$ 'de $\% 20$ biraz fazla görülmüştür.

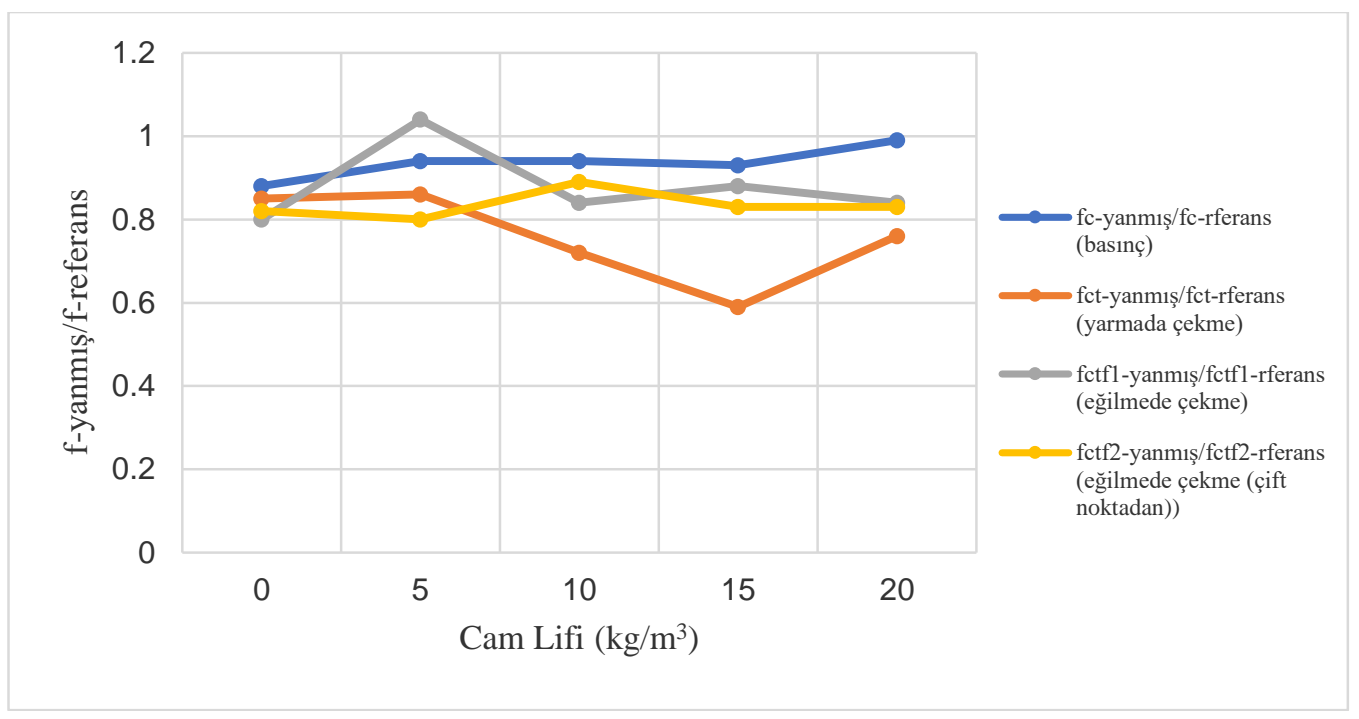

Șekil 12: Yangın sonrası dayanım değişim grafikleri

Beton malzemesinin çekme dayanımının basınç dayanıma oranı literatürde belirli katsayılarla verilmiştir. Çekme dayanımı eksenel çekme, yarmada çekme ve eğilmede çekme olarak elde edilebilmektedir ve her birinin basınç dayanımı ile olan ilişkisi farklı katsayılarla gösterilmiştir. Normal dayanımlı betonda basınç dayanımı ile çekme dayanımı arasındaki ilişki (TS 500-2000 2000)'de farklı bağıntılarla verilmiştir. Örneğin yarmada çekme için $\mathrm{fct}=0.5 \sqrt{ } \mathrm{f}_{\mathrm{c}}$ tek noktadan eğilmede çekme için $\mathrm{f}_{\mathrm{ct}}=0.7 \sqrt{\mathrm{f}_{\mathrm{c}}}$ ve çift noktadan eğilmede çekme için $\mathrm{f}_{\mathrm{ct}}=0.64 \sqrt{\mathrm{f}_{\mathrm{c}}}$ olarak verilmiştir. $\mathrm{Bu}$ çalışmada CTB'lar için yarmada çekme ve eğilmede çekme (tek ve çift noktalardan) elde edildiği için çekme dayanımları ile basınç dayanımları arasındaki ilişki yangın öncesinde ve yangın sonrasında ayrı ayrı irdelenmiştir. CTB numunelerde çekme dayanımın basınç dayanımına olan oranı lifsiz betonun değerinden daha fazladır. Bu değerlerin normal betondaki değerden yüksek olmasının temel nedeni beton içeriğinin ve kullanılan malzemelerin mekanik özelliklerinin birbirinden tamamen farklı olması ve beton içindeki liflerdir. 
Lifsiz betonda yarmada çekme dayanımının bulunmasında 0.5 olarak önerilen değer bu çalışmada kullanılan betonlarda yangın öncesi durumda ortalama 2.84 olarak edilmiştir. Yangın sonrasında ise bu oran ortalama 2.2 olarak bulunmuştur. Tek noktadan eğilmede çarpan normal betonda 0.7 iken bu çalışmada kullanılan betonlarda yangın öncesi durumda ortalama 3.84 olarak edilmiştir. Yangın sonrasında ise bu oran ortalama 3.46 olarak bulunmuştur. Çift noktadan eğilmede normal betonda 0.64 olan çarpan değeri bu çalışmada kullanılan betonlarda yangın öncesi durumda ortalama 4.40 olarak edilmiştir. Yangın sonrasında ise bu oran ortalama 3.77 olarak bulunmuştur. Bu durumda CTB numunelerinde çekme dayanımının yangının etkisiyle azaldığı görülmektedir.

\section{Tartışma ve Öneriler}

CTB üzerinde literatürde ilk kez yapılan bu çalışmada, cam lifin miktarlarına bağlı olarak betonun en önemli mühendislik özelliklerinden olan basınç ve çekme dayanımlarına değişik oranlarda etkiler yaptığı görülmüştür. Özellikle yangın geçirmemiş numunelerde basınç dayanımına bir katkıda bulunmazken çekme dayanımında önemli oranlarda katkısı olmuştur. Bu katkı özellikle eğilmede çekme dayanımında daha bariz hissedilmiştir. Burada temel etken cam lif yönü ile eksenel çekme gerilmesinin yönü arasındaki ilişki olabilir.

Cam lif miktarının artması tıpkı çelik liflerde olduğu gibi cam liflerinde topaklanarak beton içinde homojen dağılmaması problemleri oluşturabilmektedir. Bu nedenle yüksek cam lif oranlarında karışımın mümkün olduğunca homojen olması yerinde olacaktır.

Çekme / basınç dayanımı malzemenin yük altındaki gevreklik ölçütünü ortaya koymaktadır. Gevrek malzemede bu oran küçülmekteyken sünek malzemede bu oran yükselir. Normal dayanımlı bir betonda bu oran 0.06 ile 0.12 arasında değişebilmektedir. Betonarme literatüründe bu oran pratik olarak 0.1 olarak da kabul edilmektedir. CTB numunelerinde bu oranının cam lifi miktarına bağlı olarak $0.55^{\prime}$ 'lere kadar yükseldiği görülmektedir. Başka bir ifade ile cam lifi betonun sünekliğini normal betona göre yaklaşık 5.5 kat artırmıştır. Yangın geçirmiş CTB numunelerinde ise bu oranın 0.55 'lerde olduğu özellikle 30 dakikalık yangında bu oranın arttığı görülmektedir.

Yapılan karşılaştırmalarda özellikle 30 dakikalık yangın sonrasında numunelerin tek ve çift noktadan eğilme deneylerinden elde edilen çekme dayanımlarında yangın öncesine göre bir artış görülmüştür. Daha uzun süreli yangınlarda ise bu oranda bir artış meydana gelmemiştir. Yapılan bu çalışma ile cam lifi kullanılan numunelerde yangın etkisi ile dayanım değerlerinde olumsuz bir etki oluşmadığı, aksine betonun mekanik özelliklerini iyileştirdiği görülmüştür. Literatürde bunun gibi pozitif sonuçlar, Chen ve Liu (2004), Peng vd. (2008), Lau ve Anson (2006) tarafindan da bulunmuştur.

CTB numunelerinde eğilmede çekme deneyinde elde edilen çekme dayanımı değerleri yarmada çekme deneyinden elde edilen çekme dayanımı değerlerine göre daha fazla bulunmuştur. Normal betonda da buna benzer bir ilişki vardır. Bunun nedeni numunenin çekme gerilmesine zorlanan kesitinin hacminin toplam numune hacmine göre daha küçük olmasıdır. Bu nedenle eğilmede çekme dayanım değeri yarmada çekme dayanımına göre daha fazladır. Cam lif katkısı olan örneklerde ortalama ( $f_{c t}$ yarma/ $f_{c t}$ eğilme) oranı 0.64-0.74 aralığında değişirken yanmış numunelerde bu oran 0.580.63 aralığında değişmektedir. Normal betonlarda ise $\left(f_{c t}\right.$ yarma/ $f_{c t}$ eğilme) oranı $0.71-0.78$ aralığında değişmektedir. Bu durum özellikle CTB numunelerinde liflerin yönüne bağlı olarak yarmada çekme ve eğilmede çekme değerleri arasındaki farkın daha fazla elde edilmesiyle açıklanabilir.

Bu çalışmada cam liflerin yanmamış betonun çekme dayanımını \%42-\%47 arasında artırabildiği görülmüştür. Halbuki Çivici ve Eren (2004) cam lif kullanılmış betondaki çekme dayanımı artışının çelik lif kullanılmış betondaki kadar fazla olmadığını söylemektedir. Araştırmacılar bunun temel sebebini cam liflerin ince ve düz olması sonucu lif ile beton arasında oluşan aderansın daha az olması ile açıklamaktadırlar.

Betonun çekme/basınç dayanım oranı su/çimento, agrega tane çapı ve agrega özellikleri, çimento dozajı gibi parametrelere bağlıdır. Literatürde özellikle sabit su/çimento oranında artan agrega çapı ile çekme/basınç dayanımının düştüğü söylenmektedir (Arıŏlu vd. 2002). Bu sonuç CTB numuneler içinde geçerli olmuştur. CTB'nun içeriğine bakıldığında agrega tane çapının normal betona göre oldukça küçük olduğu ve kullanılan çimento dozajının normal betona göre çok yüksek olmasından dolayı çekme dayanımları normal betona göre oldukça büyük elde edilmiştir. Bununla beraber basınç dayanımını artması ile çekme dayanımı da artmaktadır.

Yaprak vd. (2004)'ne göre cam liflerin düşük oranlarda kullanılması ile (örneğin $0-1 \mathrm{~kg} / \mathrm{m}^{3}$ 'ün altında) beton içerisine dağılan binlerce lif, erken dönemde oluşan iç gerilmelerden dolayı meydana gelebilecek çatlakları, geçirgenliği azaltacak, uzun dönemde betonun atmosfer etkilerine ve dış aşındırıcı kuvvetlere karşı direncini artıracaktır. Cam lifin $5 \mathrm{~kg} / \mathrm{m}^{3} \mathrm{ve}$ daha fazla kullanılması durumunda ise karıştırma ve pompalama sırasında işlenebilirlik problemleri ortadan kalkacaktır denilmektedir. Halbuki bu çalışmada cam lif oranının artması ile karıştırma ve işlenebilme problemlerinin daha fazla olduğu bu çalışmada gözlemlenmiştir.

Literatürde (Uysal 2004) standart olarak imal edilen normal betonun yangın testlerinde basınç dayanım kayıpları \%40, eğilmede çekme dayanım kayıpları ise \%74 oranlarında bulunmuştur. Bu kayıpların CTB numuneleri ile kıyaslandığı zaman çok fazla olduğu görülmektedir. Literatürde özellikle pomza kumu, tuğla kırığı ve uçucu külle beton üretimi yapılarak yangın sonrası dayanım kayıpları \%15-20'lere kadar düşürülmüştür. Eğilme dayanımları yüksek sıcaklık etkisiyle basınç dayanımına kıyasla daha fazla azalmaktadır. Eğilme dayanımı yüksek sıcaklık sonucu oluşan hasara basınç dayanımından fazla duyarlıdır. Basınç halinde çatlakların bir bölümü kapanmaktadır. 
Yangın testlerinin yapıldığı çalışmalarda yangın süresi bir parametre olarak baz alınmaktadır. Bununla beraber sabit sıcaklık altında yapılan çalışmalarda bulunmaktadır. Bazı güncel çalışmalarda basınç ve çekme testleri ile yangın testleri iç içe geçmiş düzenekler içinde yapılabilmektedir. İleri projeksiyonlu çalışmalarda yangın düzeneğinin değiştirilmesi ile sabit sıcaklık altında testler benzer numuneler için tekrarlanabilir.

$\mathrm{Bu}$ çalışmada yangın sonrasında CTB'lerde oluşan hasarın alkali-silika reaksiyonu (ASR) açısından irdelemesi yapılmamıştır. Topçu ve Boğa'nın (2004) bahsettiği gibi özellikle çok yüksek sıcaklıklarda cam türevlerinin yapısı bozulacağı için ASR bir tehlike oluşturabilir. Bu nedenle sonraki çalışmalarda bu durum araştırılabilir. Bu çalışmada hedeflenen yangın sonrası dayanım değişikliğinin irdelenmesi olduğu için özelde bu hususa değinilmemiştir.

\section{Teşekkür}

Yazarlar çalışmaya maddi destek sağlayan Selçuk Üniversitesi Bilimsel Araştırma Projeleri Koordinatörlüğü ile numunelerin üretildiği Bursa Grand Prekast firmasına teşekkür ederler.

\section{Kaynaklar}

Ali A.M., (2017), Cam Lif Takviyeli Betonun Yangın Dayanımlarının Çeşii Parametreler Açısından İrdelenmesi, Yüksek Lisans Tezi, Selçuk Üniversitesi Fen Bilimleri Enstitüsü, Konya.

Anwar Hossain K.M., (2006), Macro-and microstructural investigations on strength and durability of pumice concrete at high temperature, Journal of materials in civil engineering, 18(4), 527-536.

Aran A., (1990), Elyaf takviyeli karma malzemeler, İstanbul Teknik Ünivesitesi, Yayını, İstanbul.

Arığlu E., Girgin C., Arığlu N., (2002), Betonda çekme/basınç dayanımı oranının irdelenmesi, Hazır Beton Dergisi, https://yapimerkezi.com.tr/PdfDosyalari/8a741b8b-77ea-4d73-9182-6ddddf893560-9e3a01ef-e165-4b8b-95c87cd39f3b10cc.pdf, [Erișim 18 Mart 2019].

Arslan, A., Ulucan, Z.Ç., (1997), Çelik liflerin erken yaştaki betonarme kirişlerin göçmesine etkisi, Teknik Dergi, 8(39), 1507-1515.

ASTM Designation: E8/E8M - 09, (2009), An American National Standard Standard Test Methods for Tension Testing of Metallic Materials, USA, https://www.coursehero.com/file/32514317/E8E8M1513pdf/, [Erișim 18 Mart 2019].

ASTM C 293, (1994), Standart Test Method for Flexural Strenght of Concrete(Using Simple Beam with Center-Point Loading), Annual Book of ASTM Standards, https://www.astm.org/Standards/C78, [Erişim 18 Mart 2019].

ASTM C496 / C496M - 17 (2011), Standard Test Method for Splitting Tensile Strength of Cylindrical Concrete Specimens, https://www.astm.org/Standards/C496

ASTM C 78, (1994), Standart Test Method for Flexural Strenght of Concrete(Using Simple Beam with Third-Point Loading), Annual Book of ASTM Standards, https://www.astm.org/Standards/C78, [Erişim 18 Mart 2019]

Bölükbaş Y., (2011), Cam elyaf katkılı beton numunelerin mekanik davranıșlarının incelenmesi ve yapay sinir ağları ile modellenmesi, Yüksek Lisans Tezi, Fırat Üniversitesi Fen Bilimleri Enstitüsü, Elazığ.

Chen B., Liu J., (2004), Residual strength of hybrid-fiber-reinforced high-strength concrete after exposure to high temperatures. Cement and Concrete Research, 34(6), 1065-1069.

Cruz C.R., Gillen M., (1980), Thermal expansion of Portland cement paste, mortar and concrete at high temperatures, Fire and materials, 4(2), 66-70.

Çivici F., Eren İ., (2004), Çelik lifli betonun direkt çekme dayaniminin ölçülmesi üzerine deneysel bir çalişma, Türkiye mühendislik haberleri 434 - 2004/6, http://www.imo.org.tr/resimler/ekutuphane/pdf/134.pdf, [Erișim 18 Mart 2019].

Cülfik M.S., Özturan T., (2002), Effect of Elevated Temperatures on The Residual Mechanical Properties of High-performance Mortar, Cement Concrete Res.,32(5), 809-816.

EN 1363-1, (2012), Fire resistance tests, Part-1, https://shop.bsigroup.com/ProductDetail/?pid=000000000030251439, [Erişim 18 Mart 2019].

EN 1634-4, (2009), Fire resistance tests, Part-4, https://shop.bsigroup.com/ProductDetail/?pid=000000000030251439, [Erișim 18 Mart 2019].

Kalifa P., Chene G., Galle C., (2001), High-temperature Behaviour of HPC with Polypropylene Fibers from Spalling to Microstructure, Cem. Concr. Res., 31, 1487-1499.

Kavas T., Sabah E., (2001), Sepiyolitin lif takviyeli çimento üretiminde kullanılabilirliğinin araștırılması, 4. Endüstriyel Hammaddeler Sempozyumu, 18-19 Ekim, İzmir, 194-199.

Keleştemur O., Arıcı E., Yıldız S., Gökçer B., (2014), Performance evaluation of cement mortars containing marble dust and glass fiber exposed to high temperature by using Taguchi method, Construction and Building Materials, 60, 17-24.

Kurt G., (2006), Lif içeriği ve su/çimento oranının fibrobetonun mekanik davranışına etkileri, Yüksek Lisans Tezi, İTÜ Fen Bilimleri Enstitüsü, İstanbul.

ISO 834-11, (2014), Fire resistance tests, https://www.iso.org/standard/57595.html, [Erişim 18 Mart 2019].

Lau A., Anson M., (2006), Effect of high temperatures on high performance steel fibre reinforced concrete, Cement and Concrete Research, 36(9), 1698-1707.

Li M., Qian C., Sun W., (2004), Mechanical properties of high-strength concrete after fire, Cement and Concrete Research, 34(6), 1001-1005.

Peng G.F., Bian S.H., Guo Z.Q., Zhao J., Peng X.L., Jiang Y.C., (2008), Effect of thermal shock due to rapid cooling on residual mechanical properties of fiber concrete exposed to high temperatures. Construction and Building Materials, 22(5), 948-955.

Riad M., Genidi M., Shoeib A.E., Elnaby S.F.A., (2015), Effect of discrete glass fibers on the behavior of RC Beams exposed to fire. HBRC Journal, 13(2), 145-151. 
Sakr K., El-Hakim E., (2005), Effect of High Temperature or Fire on Heavy Weight Concrete Properties, Cement Concrete Res., 35(3), $590-596$.

Şimşek O., Sancak E., (2005), Yüksek sıcaklığın silis dumanı ve süper akışkanlaştırıcı katkılı hafif betona etkileri, Gazi Üniv. Müh. Mim. Fak. Dergisi, 21(3), 443-450.

Tassew S., Lubell A., (2014), Mechanical properties of glass fiber reinforced ceramic concrete, Construction and Building Materials, $51,215-224$.

Topçu İ.B., Boğa A.R., (2004), Prefabrik Beton Direklerde Alkali-Silika Reaksiyonunun İncelenmesi, 11. Beton Prefabrikasyon Sempozyumu, İzmir.

TS 500, (2000), Betonarme yapıların yapım ve tasarım kuralları, Türk Standartları Enstitüsü, Ankara.

TS 802, (2009), Beton karışım tasarımı hesap esasları, Türk Standartları Enstitüsü, Ankara.

TS EN 1363-2, (2002), Yangına Dayanıklık Deneyleri-Bölüm 2: Alternatif ve ilave işlemler, Türk Standartları Enstitüsü, Ankara.

TS EN 12390-3, (2003), Beton - Sertleşmiş beton deneyleri - Bölüm 3: Deney numunelerinde basınç dayanımının tayini, Türk Standartları Enstitüsü, Ankara.

TS EN 12390-5, (2002), Beton - Sertleşmiş beton deneyleri - Bölüm 5: Deney numunelerinin eğilme dayanımının tayini, Türk Standartları Enstitüsü, Ankara.

TS EN 12390-6, (2002), Beton - Sertleşmiş beton deneyleri - Bölüm 6: Deney numunelerinin yarmada çekme dayanımının tayini, Türk Standartları Enstitüsü, Ankara.

TS EN ISO/IEC17025, (2005), Deney ve kalibrasyon laboratuvarlarinin yeterliliği için genel şartlar, Türk Standardlari Enstitüsü, Ankara.

TS 3284, (1979), Betonun eğilmede çekme dayanımını tayini deneyi (üçte bir noktalarından yüklenmiş basit kiriş metodu ile), Türk Standartları Enstitüsü, Ankara.

TS 3285, (1979), Betonun eğilmede çekme dayanımını tayini deneyi (orta noktasından yüklenmiş basit kiriş metodu ile), Türk Standartları Enstitüsü, Ankara.

Uysal A., (2004), Yüksek sıcaklı̆̆ın beton üzerindeki etkileri, Yüksek Lisans Tezi, İstanbul Teknik Üniversitesi Fen Bilimleri Enstitüsü, İstanbul.

Yaprak H., Şimşek O., Aydın Ö., (2004), Cam ve çelik liflerin bazı beton özelliklerine etkisi, Politeknik Dergisi, 7(4), $353-358$.

Yıldız T., Yıldız S., Keleştemur O., Bölükbaşı O., (2011), Atık Mermer Tozu ve Cam Lif Katkılı Betonların Basınç Dayanımlarının Yapay Sinir Ağları Ille Tahmini, e-Journal of New World Sciences Academy, 6(4), 1291-1302. 